\title{
Siyasal Partilerde Kurumsal Kimlik Çalıșmaları: Web Siteleri Üzerinden Bir Analiz
}

\author{
Yener Lütfü Mert ${ }^{1}$
}

\begin{abstract}
Öz
Kurumsal kimlikle ilgili çalışmaların uzunca bir geçmişi olmasına karşın özellikle 1980 'li yıllardan sonra akademik alanda sıkça tartışılan bir kavram haline geldiği görülmektedir. Bu tartışmaların geliştiği döneme kadar kurumsal kimlik, ağırlıklı olarak kurumsal tasarım ve markalama boyutuyla ele alınırken günümüzde, tasarım yönüyle birlikte kurum kültürü, kurum davranışı ve kurumsal iletişimi de içine alan geniş bir alanı kapsamaktadır. Özel sektörde ya da kamu sektöründe olsun tüm kurumların kurumsal kimliğe önem verme zorunluluğu hızla ortaya çıkmıştır. Demokrasinin önemli unsurlarından biri olan siyasal partiler de seçmen kitlesine ulaşmak ve onları ikna edebilmek için bu çalışmalara ağırlık vermeye başlamışlardır. Siyasal partiler kurum kimliklerini, hedef kitleye geçmişte yalnızca geleneksel iletişim kanallarını kullanarak ulaştırırken, günümüzde internet ortamında oluşturdukları web siteleri üzerinden daha hızlı bir şekilde yansıtabilmektedirler. Çalışma buradan hareketle siyasal partilerin web siteleri üzerinden kurumsal kimliklerini nasıl yansıttıklarını analiz etme amacındadır. Bu kapsamda Türkiye Büyük Millet Meclisi'nde temsil edilen dört siyasal partinin kurumsal kimlik öğeleri olarak kurumsal tasarım, kurumsal kültür, kurumsal iletişim ve kurumsal davranış tarzlarının nasıl yansıtıldığı irdelenmektedir. Araştırmanın bulgularına göre partilerin web sitelerinde kurumsal tasarım ve kurumsal iletişimi büyük oranda önemseyerek kullandıkları ortaya konulurken, kurumsal kültür ve kurumsal davranış tarzlarının yansıtılmasında yetersizliklerin olduğu tespit edilmiştir.
\end{abstract}

Anahtar Kelimeler: Kurumsal Kimlik, Kurumsal Kültür, Kurumsal Tasarım, Kurumsal İletişim, Kurumsal Davranış, Siyasal Partiler

\section{Corporate Identity Studies in Political Parties: An Analysis through Websites}

\begin{abstract}
Although researches on corporate identity have a long history, it has become a widelydiscussed concept in the academic environments since 1980s, in particular. Whilst corporate identity had mainly been related to corporate design and branding aspects until 1980s, today the concept covers an extensive area including not only the design aspect but also corporate culture, corporate behaviour and corporate communication aspects. The obligation to give utmost importance to corporate identity has quickly emerged for all companies, whether they operate in public or private sectors. Even political parties, which are amongst fundamental components of democracy, have also
\end{abstract}


started to work on their corporate identities to reach out the electorate and convince them. Whilst political parties used to inform the target electors about their corporate identities through traditional means of communication, today they can reflect their corporate identities faster through their websites. Starting from this point of view, this study aims to analyse how political parties reflect their corporate identity through websites. Websites of the four political parties that achieved to get into the Turkish Grand National Assembly were examined in detail as part of the study. The study has the purpose to find out how their corporate identities are reflected through their corporate designs, corporate cultures, corporate communications and corporate behaviours, which are the components of their corporate identities. According to the survey results, it has been observed that the political parties give utmost attention to their corporate designs and corporate communications through their websites; however, deficiencies have been detected in the manner they reflect their corporate cultures and corporate behaviours.

Keywords: Corporate Identity, Corporate Culture, Corporate Design, Corporate Communications, Corporate Behaviour, Political Parties 


\section{Giriș}

$\mathrm{B}$ ir kurumu diğerlerinden ayıran en temel özelliklerden biri kurumsal kimliğidir. Kurumsal kimliğin hedef kitleye doğru ve istenilen şekilde aktarılması, gerek kurum içi gerekse kurum dışında bırakmak istediği ya da bıraktığı etkiyle ölçülebilmektedir. Geçmişte orduların veya devletlerin kendilerini farklı kılmak için oluşturdukları birtakım ayırt edici semboller kullanmasından günümüze gelene dek önemli dönüşümler geçiren kurumsal kimlik yapılanması, halkla ilişkiler çalışmalarında önemli bir başlığı oluşturmaktadır. Önceleri yalnızca kurumun sembol ve simgeleri üzerinde görülen bu çalışmalar, günümüzde halkla ilişkiler alanının gelişimiyle profesyonel bir şekilde kurumun birlikteliğini sağlayan, ortak ruhu oluşturan davranış ve vizyonu da içine alan bir özelliğe kavuşmuştur. Dolayısıyla kurumun ne olduğu, ne yaptığı, ne yapmak istediği, nasıl göründüğü ve kendini nasıl ifade ettiği gibi unsurların tümü bu çalışmalar içinde değerlendirilmektedir. O halde başarılı olmak isteyen kurumlar, kurumsal kimlik çalışmalarına bütüncül bir bakış açısıyla bakmak zorundadırlar denilebilir.

Her siyasal partinin ülke yönetimine talip olduğu düşünülürse hedef kitle olarak seçmenlerin oy verecekleri, ülke yönetiminde görmek istedikleri partileri seçebilmeleri için partilerle ilgili daha kapsamlı bilgilere ihtiyacı vardır. Partilerin iyi bir iletişim süreciyle halkın beklenti ve algısını doğru değerlendirmeleri ve bunun karşılığında nasıl bir imaj oluşturacaklarına karar vermeleri beklenmektedir. Bu sürecin oluşturulabilmesi için kurumsal kimlik oluşumunun doğru konumlanması ve ifade edilebilmesi gerekmektedir. Partilerin yaptığı bu çalışmalar geleneksel halkla ilişkiler araçlarından hedef kitleye aktarılabildiği gibi son yıllarda hızla yaygınlaşan internet teknolojisini iyi kullanarak daha da geliştirilebilmektedir. Bu bağlamda siyasal partilerin web siteleri hem iç hem de dış hedef kitleye açılan bir kapı olarak görülmektedir. Web siteleri, hızlı ve anlık bilgi paylaşımını sağlamanın yanı sıra istenilen geniş kapsamlı bilgiyi içinde barındırması açısından da önemlidir. Siyasal partiler kurumsal web sayfaları üzerinden bir yandan küresel ölçekte seçmen kitlesine ulaşırken, diğer yandan kitlelerden gelecek yorum ve önerileri anında değerlendirmeye alabilmektedir. Dolayısıyla siyasal partilerin de özel işletmelerde olduğu gibi dinamik bir web sayfasına sahip olması ve partinin bu kanaldan açık bir şekilde sunulması zorunlu görünmektedir.

$\mathrm{Bu}$ çalışma, siyasal partilerin kurumsal kimliklerini, web siteleri üzerinden nasıl yansıttıklarını ortaya koymayı amaçlamaktadır. Bu kapsamda öncelikle kurumsal kimlik kavramının gelişim süreci ile birlikte kurumsal kimliği oluşturan kurumsal davranış, kurum kültürü, kurumsal tasarım ve kurumsal iletişim kavramları incelendikten sonra siyasal partilerin web sayfalarında bu işlevleri nasıl yansıttıkları analiz edilecektir. Analiz için Türkiye Büyük Millet Meclisi'nde (TBMM) grubu bulunan dört partinin web sayfası örneklem seçilerek Türkiye'de siyasal partilerin kurumsal kimlik çalışmalarının nasıl yansıtıldığı yönünde değerlendirmede bulunulacaktır.

\section{Kurumsal Kimlik Kavramsallaștırması}

Kurumları diğerlerinden ayıran ve fark edilebilirliği sağlayan temel özelliklerden biri olan kurumsal kimlikle ilgili tanımlamalara bakıldığında kavramın farklı yönleriyle değerlendirilerek birçok anlam yüklendiği görülmektedir. Kavramın tarihsel uygulama süreci izlendiğinde, aslında günümüzdeki tanımlamaların işaret ettiği bakış açısının, ilgili dönemlere yönelik bir düşünce sürecini gösterdiği görülebilir. O nedenle öncelikle 
kurumsal kimliğin gelişim sürecini kısaca değerlendirdikten sonra tanımlamaların daha anlamlı olacağı düşünülmektedir.

Her ne kadar günümüzdeki anlamıyla olmasa da kurumsal kimlik uygulamalarına İlk Çağ Yunan devletlerinden bu yana çeşitli şekillerde rastlamak mümkündür (Meech, 2002:127; Jefkins, 1995: 33). Orta Çağda kilisenin Hristiyan kökenli ülkeleri elde etme çabasıyla haç işaretini bir sembol olarak kullanması (Erdoğan, 2012: 43), 15. yüzyılda Floransa yöneticilerinin kentin Malta'dan ayrı bir yerleşim olduğunu gösterebilmek amacıyla sanatçılar ve mimarlar görevlendirerek Floransa'nın resmini yaptırmaları ile 19. yüzyılın son çeyreğinde İngilizlerin Hindistan'daki sömürge prensliklerini ayırt edebilmek adına arma memurluğu oluşturarak prenslikler için armalar oluşturulması (Okay, 2013: 2) bu örneklerden yalnızca birkaçıdır. Ağırlıklı olarak görsellik sunumu şeklinde gerçekleştirilen bu çalışmaların temelinde kurum, devlet veya organizasyonların ayırt edici özelliklerini ön plana çıkarma durumu söz konusudur.

Kurumsal kimlik uygulamaları 19. yüzyılda sanayinin gelişmesi paralelinde örgütlerin çeşitlenmesi ve rekabetin bir gereği olarak özellikle özel sektör yapılanmalarında görülmeye başlanmış ve 20. yüzyılın başlarından itibaren de profesyonel anlamda gerçekleştirilen bir çaba olmuştur. Tarihsel açıdan bakıldığında bu süreci kendi içinde dört aşamada değerlendirmek mümkündür (Okay ve Okay, 2012: 506): "Geleneksel dönem" olarak adlandırılan ve Birinci Dünya Savaşının sonuna dek süren ilk uygulamalarda ağırlıklı olarak kuruluş sahibinin firmanın tüm kimliğini biçimlendirdiği görülür. İki dünya savaşı arasındaki dönemi kapsayan ve "marka tekniği dönemi" olarak adlandırılan dönemde kurumsal kimlik, kurumların sahip olduğu markalar ön plana çıkarılarak uygulanmıştır. İkinci Dünya Savaşından 1970'li yıllara kadar süren ve "dizayn dönemi” olarak adlandırılan dönemde kurumsal kimlik uygulamaları kurumsal tasarıma dayalı olarak ortaya çıkmıştır. Son olarak günümüze kadar gelen 1970’li yıllar sonrası "stratejik dönem" şeklinde adlandırılan dönemde kurumsal kimlik, öncekilerden çok daha geniş anlam alanına kavuşmuştur. Bu dönemin temel özelliği, kurumsal kimliğin, kurumsal tasarımın ötesinde kurum felsefesi, kurumsal davranış ve kurumsal iletişimi de kapsayan bir niteliğinin olduğu düşüncesine dayanmasıdır.

Uygulama dönemlerinden görüldüğü üzere kurumsal kimlik, günümüzde stratejik yönetimin bir parçası olarak farklı disiplinlerle ilgili bir yapıyı ortaya koyarken, alana ilişkin tanımlamalar da buna uygun olarak gelişmeye başlamıştır. Kurumsal kimliğin, kurumsal iletişim çalışmaları temelinde oluşturulan bir süreç olması (Bat, 2014: 383) nedeniyle uygulamanın ortaya konulması da kuşkusuz halkla ilişkilerin sorumluluk alanına (Jefkins, 2003: 33) girmektedir. Bununla birlikte kavramın1970’li yıllardan sonra stratejik amaçlar bağlamında kullanılması nedeniyle kurumsal kimlik stratejik yönetim, psikoloji, pazarlama ve örgütsel davranış gibi diğer akademik disiplinlerle de ilintili bir şekilde ortaya konulmaktadır (Melewar, 2003: 177). Doğal olarak alana ilişkin tanımlamalarda bu gelişmenin izini sürmek mümkündür.

Bu kapsamda kavrama ilişkin tanımlamalara bakılacak olursa literatürde üç temel yaklaşımın sergilendiği görülmektedir. Bunlardan ilki kurumsal kimliği görsel tasarım düzleminde ele alırken, ikinci yaklaşım kurumun bütünleşik iletişimi olarak görmekte, üçüncü yaklaşımda ise kurumların bir davranış süreci kapsamında disiplinler arası bir alan olduğu vurgulanmaktadır (Van Riel ve Balmer, 1997: 340). 
Jefkins'e (2003: 33) göre kurumsal kimlik, kurumların birbirlerinden ayırt edilmesini sağlamak ve görsel olarak tanınmak için gerçekleştirilen bir çabadır. Bu çaba logo, tipografi, renk ve hatta çalışanların giydiği özel tasarımlı elbise gibi örneklerle görünür hale gelmektedir. Kurumsal kimliğin belirgin olarak kullanıldığı yere örnek olarak havayolları ve taşımacılık firmaları verilebilir.

Kurumsal kimliği bir yandan görsel dizayn olarak değerlendiren Robin Cobb, kavramın aynı zamanda kurumların yapı ve felsefesini de ifade ettiğini belirtmektedir (Cobb, 1998'den aktaran Okay, 2013: 28). Kurumsal kimliğin stratejik bir yönetim fonksiyonu olduğuna dikkat çeken dünyaca ünlü kurumsal kimlik uzmanı Wally Olins (1989:224),her kurumun bağımsız bir kimliğe sahip olması gerektiğini ve bunun ancak kurumun yaptığı tüm faaliyetlerinin hedef kitlelere doğru aktarılmasıyla gerçekleşebileceğinin altını çizmektedir. Konuyu geniş kapsamda değerlendiren Vural ve Bat (2013: 89) ise kurumsal kimliğin, bir kurumun çalışanlarının davranışlarını, iletişim biçimlerini, felsefesini ve görsel unsurlarını kapsadığını belirtmektedir. Buna göre aslında kurum, kurumsal kimlik uygulamalarıyla nihayetinde kurumsal imajını da oluşturmaktadır. Diğer bir tanımlamaya göre kurumsal kimlik, bir kurumun uzun dönemde stratejik bakış açısıyla planladığı amaçlarına ve ulaşmak istediği imaja sahip olabilmek için kurum kişiliğini iç ve dış hedef kitlelere aktarabilmesidir. Kimlik kavramı bu kapsamda kurumun diğerlerinden ayırt edilebilen ve hatırda kalan özelliklerini kapsamaktadır (Budak ve Budak, 2014: 176).

Kurumsal kimlik çalışması yukarıda belirtildiği üzere stratejik yönetimin önemli bir unsurudur. Doğru uygulanan kurumsal kimlik çalışmaları kurum dışı hedef kitlede olumlu algı yaratacağı gibi iç hedef kitlede de "biz" duygusunu oluşturacaktır. Bu durumun yansıması, doğal olarak çalışanların ve aynı zamanda yöneticilerin motivasyonunu artıran bir olgu olarak ortaya çıkacaktır. Diğer taraftan kurumsal kimliğini doğru bir şekilde geliştiren ve yöneten kurumlar rekabet ortamında iyi bir imajla bir adım daha önde yer alacaklardır. Kurumsal kimlikle ilgili literatürde yer alan tanımlamalar kavramın hem farklı sosyal disiplinlerle bağlantısını hem de geniş kapsamlı bir alana içkin olduğuna işaret etmektedir.

Fidan ve Gülsünler'in (2003: 467) de ifade ettiği gibi kurum kimliği, "kimlik oluşturmak amacını taşıyan planlı, bilinçli olarak kullanılan, arzulanan imajın oluşturulmasını hedefleyen ve ifade edilmiş kurum felsefesine dayanan bir yönetim aracı" olarak iç ve dış hedef kitle açısından birtakım önemli yararlar sağlamaktadır. Bunlar şu şekilde özetlenebilir (Melewar, 2003: 176-177):

- Kurumsal kimlik, çalışanları motive eden merkezi bir güç niteliği taşımaktadır. Çalışanlar, örgütlerinin amaç, hedef ve özelliklerini açık bir şekilde anlarlarsa örgütlerine daha büyük bir destek ve bağlılık duygusu yaşamaktadırlar.

- Kurumsal kimlik, çalışanların var olan kültüre daha büyük bir duyarlılıkla uyum göstermelerini sağlamakta ve bir birleşme ya da satın almanın ardından yeni kültürün bütünleşmesini kolaylaştırmaktadır.

- Kurumsal kimlik, örgütlerin yüksek vasıflı yöneticileri kendisine çekmesine yardımcı olmaktadır. 
- Örgütün paydaşlarının, kurumsal kimliğin yansıması sayesinde iş kapasitesi, yönetim gücü, rekabetçilik ve ürün/hizmet çeşitliliğinin farkına varması kolaylaştırılabilir.

- Hedef kitle, kurumsal kimlik aracılığıyla ürün/hizmet kalitesi ile ilgili bilgilendirilebilir ve bu şekilde örgütün ürün ve markasına destek sağlanabilir.

- Kurumsal kimlik, paydaşların bağlıı̆̆ını sağlayan güçlü bir kurumsal marka oluşmasına katkıda bulunabilir.

- Kurumsal kimlik sayesinde finansal topluluğun kurumu iyi kavraması sağlanabilir. Bu sayede yatırımcıların dikkati çekilerek şirketin varlıkları daha adil bir biçimde değerlendirilip örgütün sermaye piyasalarına ulaşma şansı artırılabilir.

Kurumsal kimlik, stratejik yönetim bağlamında ele alındığında onu oluşturan bileşkelerin her birinin doğru kurgulanmasının gerekliliği ortaya çıkmaktadır. Son dönem tanımlamalarda altı çizilen kurumsal kimliğin etkileşim halinde olduğu bu bileşkeler kurumsal tasarım, kurumsal kültür, kurumsal iletişim ve kurumsal davranıştır. Kimliğin doğru oluşturulabilmesi için bu bileşkelerin sağlıklı bir şekilde kurgulanması ve uygulamaya dökülmesi gerekmektedir. Dolayısıyla öncelikle bu alanların kurumsal kimlik içindeki yeri ve önemi ele alınmalıdır.

\subsection{Kurumsal Tasarım}

Kurumsal tasarım veya kurumsal sunum, temelde logo tasarımıyla başlayıp bu tasarımların, kurumun tüm basılı ve görsel materyallerine yansımasıdır. Logo tasarımında renk seçimiyle başlayan süreç isim, yazı, tipografi ve sembollerle desteklenerek ortaya konulmaktadır (Melewar, 2005: 380). Seçilen bu öğeler bir anlamda kurumun hedef kitleye kendini ifade etme biçimidir. Dolayısıyla görsel tasarım, kurumu diğer kurumlardan ayırıcı özelliklere sahip ve hedef kitlenin aklında kalıcılığı sağlamaya yönelik bir çabayı işaret etmektedir.

Seçilen tasarım öğeleri, kurumun tüm basılı ve görsel materyallerinde hiçbir değişikliğe uğratılmadan kullanılmaktadır. Bu bağlamda kuruma ait görsel tasarımın başlıca kullanım araçları olarak antetli kağıt, kartvizit, tabela, kurum içi yayınlar, mekan düzenlemesi, broşürler, afişler, bina mimarisi, fuar stantları, iş elbiseleri sayılabilir. Bunların yanı sıra kurumların web sitesi tasarımlarında kullandığı renkler, yazı karakterleri, kuruma ait ön plana çıkarılan semboller de kurumsal tasarım araçları arasında yer almaktadır.

Diğer yandan kurumsal tasarımın temelini oluşturan logolarda kullanılan renklerin insan psikolojisine yapacağı etkinin doğru değerlendirilerek oluşturulması ile birlikte aynı zamanda daha geniş bir bakış açısıyla kurumun geçmişini, temel bakış açısını ve çağdaş teknolojiyi sembolize eden bir nitelikte olması gerekmektedir. Bunun için bir logo tasarımında öncelikle iyi bir araştırma yapılması, beklenti ve intiyaçların belirlenmesi, dünyada yapılan uygulamaların incelenmesi gerekmektedir.

Kurumsal tasarım, profesyonel bir ajans çalışmasını gerektirmektedir. Özellikle 
Türkiye'de büyük kurumsal organizasyonlar dışında bu çabanın yeterince olmadığı, profesyonel ajanslara logo çalışmasının yaptırılmadığı görülmektedir. Bunun nedeninin hem sürecin uzun olması hem de kurumlardaki ekonomik yetersizliklerden kaynaklandığı söylenebilir. Ancak örgütü diğerlerinden ayırıcı özelliği ve hatırda kalabilmesi niteliğiyle logo tasarımlarının uzun dönemli kullanıldığı dikkate alınarak profesyonel bir çalışmayla gerçekleştirilmesi, kurumsal kimlik temelinin sağlam atılması noktasında gerçekten önemli bir sürece işaret etmektedir.

Kurumsal tasarım faaliyetlerinin yönetimin etkinlik ve verimlilik prensiplerine aykırı olmaması gerekmektedir. Bu bağlamda kurumsal tasarımın; kullanımının kolay olması, kullanma ve uygulamada güvenilir olması, estetik olması ve verdiği mesajlarla amaca hizmet etmesi hususu ön planda tutulmalıdır (Tuna ve Tuna, 2007: 74). Ayrıca her tasarımın kurumlara özgü nitelikte olması önemsenmeli, farklı kurumların tasarımlarıyla çağrışımı olmamalıdır.

Kurumsal tasarımlarda belirli dönemlerde değişiklik yapılabilmektedir. Değişikliğin gerekçesi dönemsel intiyaç ve kurumun kendini yenileme süreciyle bağlantılı olabileceği gibi bir kurumun farklı kurumlarla aynı çatı altında birleşmesi şeklinde de olabilmektedir. İlkine örnek olarak AEG'nin kurumsal tasarımındaki değişiklikler verilebilir. 1896'da yapılan ilk logo çalışmasının ardından 1907 yılında tasarımcı ve mimar Peter Behrens tarafından yenilenen logo çalışması, çeşitli tarihlerde logo üzerinde özellikle tipografik anlamda değişiklikler yapılarak günümüze kadar gelmiştir. İkinci bakış açısına uygun örnek olarak Türkiye'de iletişim sektöründe hizmet veren Türk Telekom'un geçirdiği evreler verilebilir. Türk Telekom, uzun yıllar tek bir kuruluş olarak hizmet verirken 2016 yılı Şubat ayında Avea ve TTNET ile birleştikten sonra yeni bir kurumsal tasarımla hedef kitlelerin karşısına çıkmıştır. Birleşme sonrası tüm kurumsal tasarım faaliyetleri yenilenerek reklam ve kullanılan basılı materyallere kadar aynı logo tasarımı kullanılmaya başlanmıştır. Çalışmanın temelinde birleşme olgusuna önem verildiği gözlenmektedir.

\subsection{Kurumsal Kültür}

Kurumsal kimliği oluşturan önemli bir unsur olan kurumsal kültür kavramı çeşitli kaynaklarda örgüt kültürü, işletme kültürü, kurum kültürü gibi farklı adlandırmalarla yer almaktadır. Bugünkü anlamıyla olmasa da çok eski dönemlerden beri uygulanan geleneksel anlamda kurumsal kültür, özellikle 1980'li yıllarda rekabetin yoğunlaşması ve kurumların bu bağlamda yeni organizasyonel bakış açıları geliştirmeleri kapsamında sıkça kullanılır duruma gelmiş, akademisyenler tarafından çeşitli unsurlarıyla tartışmaya açılmıştır.

"Bir örgütün içindeki insanların davranışlarını yönlendiren normlar, davranışlar, değerler, inançlar ve alışkanlıklar sistemi" (Dinçer, 1992: 271) olarak ifade edilen kurumsal kültür, kurumsal kimliğin oluşup yeni gelen çalışanlara aktarımasında önemli bir alanı işaret etmektedir. Dolayısıyla kurum kültürü, kurumun misyon, amaç, ortam ve başarısı için gerekli intiyaçlar nedeniyle ortaya çıkmaktadır (Okay, 2013: 194). Genel anlamda bakıldığında kültürün uzun bir süreçte oluştuğu ve sonraki dönemlere aktarıldığı kabul edildiğinde, sözü edilen kavramların kurumlarda gelişme sürecinin yeni oluşum aşamaları dışında verili değerlerin aktarılması olarak da önem kazandığı görülebilir. 
Kurumsal kültürün ortak anlayış paralelinde organizasyonlarda geliştiğine dikkat çeken Akıncı (1998:150) kurumsal kültürü "kurum tarafından benimsenen temel değerler ve örgüt üyelerince paylaşılan ve herkesin içinde hareket ettiği ortak anlayış ve temel inanç sistemi" olarak değerlendirmektedir. Dolayısıyla kurumsal kültür, inanç ve değerlere bağlılık olarak görünürlük kazanmaktadır (Budak ve Budak, 2014: 180). Kurumsal kültürün kurumun baskın değerleri olduğunun altını çizen Deal ve Kennedy (1982) ise bu çekirdek değerlerin hangi ürünün üretileceğini ve çalışanlara nasıl davranılacağını belirlediğini vurgulamaktadır (aktaran Sriramesh vd., 2005: 607).

Tanımlamaların ortak bakış açısı, kurumsal kültürün örgüt üyelerince paylaşılan bir değerler bütününden oluşmasına yöneliktir. Bu değerler, kurumun üyelerine doğru veya yanlış, kabul edilebilir ya da kabul edilemez davranışların neler olduğu hakkında bilgi verme amacına yöneliktir. Örneğin, bir kurumun temel değerleri arasında müşterinin daima haklı olduğu bilinci varsa müşterinin talep ve beklentilerine uygun hareket edilmekte ve müşteriyle bu konuda tartışmaktan kaçınılmaktadır. Yani bu değerler kabul edildikten sonra konu çalışanlarca artık tartışılmamaktadır. Diğer taraftan kültürün zaman içinde uygulamalardan oluştuğu varsayımından hareketle kurumsal kültürün genel kabuller temelinde ortaya çıktığı görülmektedir (Vural, 2012: 43-44). Yazılı olmayan değerler, açıkça ifade edilmemesine rağmen çalışanların kurum içindeki tüm davranışlarını şekillendirmektedir.

Kurumsal kültürünün üç temel noktada işlevinin olduğu kabul edilmektedir. Bunlardan ilki, kurum kültürünün bütünleştirme özelliğidir. Kurum kültürü, çalışanlarla kurumu bütünleştirme amacı üzerine konumlanmıştır. İkincisi, davranışlara ilişkin kodlamalar oluşturmakta, böylece davranışları yönlendirici etkide bulunmaktadır, hatta genel anlamda koordinasyonun sağlanmasına da yardımcı olmaktadır. Üçüncü olarak güçlü bir kurum kültürü yalnızca kurumun genel anlayışını etkilemekle kalmamakta, aynı zamanda çalışanlarda anlayış değişikliği oluşturma ve motive etme işlevine destek sağlamaktadır (Okay, 2013: 206). Bu özellikleri nedeniyle kurum kültürü, kurumun başarısını ve hedeflere aynı ruhla bakabilmeyi beraberinde getirmektedir. Çalışanlar, örneğin bir sorunla karşılaştıklarında bu değerlerin ışığında nasıl karar vermeleri gerektiğini başkalarına sormadan uygulayabilmektedirler.

Hofstede (1994: 9)kurum kültürünü oluşturan öğelerin, dairesel bir düzlemde içten dışa doğru değerler, törenler, kahramanlar ve semboller olduğunu ifade etmektedir. Lewis'e (1998: 254) göre ise örgüt kültürü üç temel katmandan oluşmaktadır. Geniş bir alanı kapsayan ilk katmanda semboller, süreçler, biçimler ve davranışlarla birlikte duygular, inançlar ve değerler oluşmakta, değerler de kurumun temel varsayımları, yani kültürünü oluşturmaktadır. Schein de (1997: 7) benzer bir sonuç oluşturan sınıflandırmasında örgütsel yapı ve süreçler olarak gözlenebilir düzenlemeler; strateji, amaç ve felsefeleri yansıtan benimsenen değerler ile temel varsayımların yani bilinçdışı inançlar, algılamalar ve duyguların etkileşimli olarak kurum kültürünü ortaya çıkardığını belirtmektedir.

Bu görüşler ışığında bakıldığında geniş bir alanı kapsayan kurum kültürünün birçok unsurun bir araya gelmesiyle oluşan bir bütün olduğu görülmektedir. Bu unsurlar arasında temel değerler, normlar, varsayımlar ile kurumun görülebilen ifade biçimleri olarak seremoni ve törenler, adetler (ritüeller), mitler, semboller, dil ve kahramanlar sayılabilir (Güçlü, 2003: 150). 
Temel Değerler: Kurumun temel anlayış sistemini oluşturan değerler, hem iç hem dış hedef kitleyle bütünleşme sorunlarının çözümünde kullanılmaktadır. Hatta birçok akademisyen ve uygulamacı, kurumu, kurucusunun, yöneticisinin ve bireylerin paylaştığı değerlerin bir göstergesi olarak görmektedir. Yönetici ve çalışanlar bu değerler sistemi üzerinden hareket etmektedirler. Değerler, bazen yöneticiler tarafından yazılı hale getirilerek ortaya konulmaktadır. Bu durum, temel kurumsal anlayışın belirtilmesi, kurum felsefesi, firma andı, firmanın prensipleri, vizyonu ve misyonu olarak sunulmaktadır (Vural, 2012: 159).

Normlar: Kurumlarda neyin doğru neyin yanlış olduğu konusunda gizli bir ortaklığın oluştuğu yazılı olmayan kurallar bütünüdür. Diğer bir deyişle normlar, "grup üyeleri tarafından kabul edilen ve onlardan beklenen düşünce ve davranış standartlarıdır" (Erkmen, 2010: 50). Çalışanların davranışlarına yön veren normlar değerlerin yansımasıdır ve bir örgütün tüm üyeleri tarafından paylaşıldığı için ortak nitelik taşımaktadır. Çalışanların kurum içinde nasıl davranmaları gerektiği, ilişkilerin nasıl kurulacağı ve paylaşımların ne şekilde gerçekleştirileceği gibi eylemleri ortaya çıkaran bir sistemdir. Dolayısıyla normlar genel olarak kurumun çalışanlardan beklediği davranışı da ortaya koymaktadır (Güçlü, 2003:151).

Varsayımlar: Benzer sorunların sürekliliği halinde bulunan çözüm yollarının bir süre sonra tartışılmadan kabul edilir hale gelmesiyle çözüm stratejileri varsayım olarak yerleşmektedir (Doğan, 2012: 52). Varsayımlar, tartışmaya açık değildir ve sorgulanmadan kabul edilmektedirler (Schein, 2004: 21).

Seremoni ve Törenler: Törenler, özel bir fikrin iletilmesi veya belli bir amacın gerçekleştirilmesi için yapılan seremonik etkinliklerdir. Törenler, örgütsel düzenin devamını sağlamak, işe yeni başlayanlara kurumu tanıtmak ve sembolik mesajları çalışanlara aktarmak şeklinde gerçekleştirilmekte ve kuruma bağlılık duygusunun gelişmesini amaçlamaktadır (Bakan vd., 2004:60). Kuruluş yıldönümü etkinlikleri, kurucunun anılması, çalışanlara ödüller verilmesi, çalışanlara yönelik etkinliklerin düzenlenmesi, tören ve seremonilere örnek olarak gösterilebilir. Böylece kurumsal bakış açısının çalışanlarda kalıcı hale getirilmesi ve "biz" duygusunun oluşturulması hedeflenmektedir.

Adetler (Ritüeller):Adetler, kurum içerisinde kültürel değerleri güçlendirmek amacıyla yapılan, önemsenen ve tekrarlanan etkinliklerdir (Bakan vd., 2004: 63). Adetler, yazılı olabileceği gibi genellikle doğrudan uygulama şeklinde ortaya konulmaktadır. Konuşmalar, yazışma şekilleri, gruba katılanların diğerleriyle tanıştırılması, yemek düzenlenmesi veya toplantıların belli bir düzende olması gibi pek çok şekillerde uygulanabilmektedir. Adetler, çalışan ve yöneticilerin kuruma aidiyet duygusunu kazandırmada önemli role sahiptir.

Mitler: Kurucular, başarılı çalışanlar ve kurumun yetiştirdiği ünlü isimlere atfedilen doğru olsun veya olmasın çalışanları motive eden efsanelerdir (Vural, 2010: 164). Bu efsaneler bazen kuruluş yıllarında yaşanan zorlukların üstesinden gelinerek kısa sürede başarının yakalandığının öyküleştirilmesi şeklinde olabileceği gibi bazen de kurucunun özelliklerinin yüceltilerek kurumun özellikle işe yeni başlayanların gözünde önemli bir noktaya oturtulması amacını gütmektedir. Kurumun tarihinde yaşanmış veya yaşandığı varsayılan efsaneleşmiş öyküler, çalışanların motivasyonunu güçlendirmenin 
yanı sıra yeni başlayanların o kurumda çalışmanın ne olduğunu kavraması açısından da önemlidir.

Liderler ve Kahramanlar: Temel değerler ve inançlar nasıl kurum kültürünün temelini oluşturmaktaysa liderler ve kahramanlar da bu değerleri simgeleyip ortaya koyan o kültürün temsilcisidirler. Çalışanlar, kurumda rol modeli olarak onları görmektedirler. Kahramanlar geçmişte yaşamış kişiler olabileceği gibi, yaşayanlar hatta hayali kişiler de olabilmektedir. Dolayısıyla özellikle liderler, kurum kültürünü çalışanlara aktarmada dikkatli davranarak onların yönlendiricisi ve gözünde yücelttiği kişiler olarak davranmak durumundadırlar.

Semboller: Objeler, flamalar, bina, mekan düzenlemesi ve kıyafetler kurumun görünen yüzünü oluşturan sembollerdir. Bununla birlikte kurumun öncüleri olarak kendilerine önemli kurumsal değerler atfedilen kişilerin çalışanlar tarafından sembolize edilmesi şeklinde de gerçekleşebilir. Semboller çalışanların kurumla bütünleşmesinde ve motive edilmesinde etkili bir araç olarak değerlendirilmektedir (Okay, 2013: 211-213).

Dil:Her kurumun kendine özgü bir dili vardır. Çalışanlar kuruma ait dili öğrenerek kabul ederler ve kurum kültürünün sonrakilere iletilmesine katkı sağlarlar. Kuruma ait dil içerisinde argo ifadeler, mecazlar, şakalar, metaforlar, sloganlar ve sözel semboller yer almaktadır. Her kurum hizmet verdiği alana göre farklı dil geliştirebilmektedir (Uzoğlu, 2001: 243).

\subsection{Kurumsal İletișim}

Kurumsal iletişim, "kuruma veya organizasyona karşı, kamuoyunu ve işletme iklimini etkileme hedefi olan tüm iletişim tedbirlerinin sistematik bir biçimde kombine edilerek uygulanmasıdır" (Okay, 2013: 149). Olins, kurumsal iletişimi, kurumsal kimliği oluşturmak için kurumun iletişim kurarken yaptığı her şey olarak değerlendirmektedir (Melewar, 2003: 180). Riel (1995: 24-25) ise kurumsal iletişimin bir yönetim aracı olduğuna dikkat çekerek gerek iç gerekse dış iletişim çabalarının bilinçli kullanılan tüm alanlarının, kurumun hedef kitlesinde bir temel yaratacak şekilde etkin ve verimli şekilde uyumlulaştırıldığı bir araç olduğunu ifade etmektedir. Tanımlara ek olarak kurumsal iletişim, literatürde geniş kapsamlı bir şekilde ele alınmış ve kurumsal iletişimin bileşenleri olarak yönetim iletişimi, organizasyonel iletişim ve bütünleşik pazarlama iletişimi kavramsallaştırmalarıyla bütünleştirilmiştir (Tosun, 2003: 176). Kurumsal iletişim geniş anlamda yönetsel iletişim, kurumun bütün iletişimi, pazarlama iletişimi, halkla ilişkiler, medya ilişkileri, kriz iletişimi, müşteri ilişkileri yönetimi, marka yönetimi, kurumsal imaj ve kurumsal itibar gibi kuruma ilişkin temel iletişim alanını kapsamakta ve düzenlemektedir (Bat, 2014: 384). Bu özellikleri nedeniyle kurumsal iletişim, yalnızca halkla ilişkiler çalışmalarını kapsamakla kalmamakta, aynı zamanda reklam, iç iletişim, kurumsal tasarım, sponsorluk, promosyon gibi işletme yönetimi alanlarını da içine almaktadır. Dolayısıyla kurumsal iletişimin, kurumun temel amaçlarını gerçekleştirmek için diğer unsurlarla birlikte kurumsal kimliği oluşturmada başat bir niteliğe sahip olduğu söylenebilir.

Kurumların hedef kitlelerin tutumlarını değiştirmek veya yeni davranış tarzları oluşturabilmek için kurumsal iletişimi, kurumsal yapının diğer elemanlarıyla birlikte değerlendirmesi gerekmektedir. Atak (2005: 60), iletişimin bu özelliğini şöyle ifade etmektedir: 


\begin{abstract}
"Örgütlerin amaçlarına ulaşabilmeleri bu sürece bağlıdır. Bu nedenle örgütsel iletişimin, yönetimin temel fonksiyonlarından biri olduğu söylenebilir. Çünkü örgütlerin belirlenen amaçlara ulaşabilmeleri, örgüt unsurlarının bu amaç doğrultusunda bir araya gelmesini gerektirir ki; bu faaliyetler dizisi, yönetimin örgütleme fonksiyonu ile olur. Her örgütleme ve koordinasyon fonksiyonunun zorunlu unsuru iletişimdir. İletişim olmadan örgütleme ve koordinasyon yürütülemez."
\end{abstract}

Kurumsal iletişimi çeşitli şekillerde sınıflandırmak mümkündür. Bunlar arasında biçimsel-biçimsel olmayan iletişim, kurum içi-kurum dışı iletişim, kontrol edilebilenkontrol edilemeyen iletişim türlerini saymak mümkündür. Biçimsel iletişim, belirlenmiş kurallar paralelinde gerçekleştirilen, kurum çalışanlarından soyutlanmış statüler arası bir iletişim türü iken, biçimsel olmayan iletişim, çalışanların oluşturduğu gruplar ve bu gruplar arasında gelişen kişiler arası iletişimdir (Karcıoğlu vd., 2009: 65-66). Kurumsal iletişimin diğer bir boyutu olan kurum içi ve kurum dışı iletişim, çalışanlarla paydaşlar ve kurum dışındaki hedef kitleyi kapsamaktadır. Kontrol edilemeyen iletişim genellikle kurumun çalışanları ve dış hedef kitle arasındaki ilişkilerle oluşan iletişimi kapsamaktadır. Telefonlarda müşteri ile kurulan iletişim, davranış şekli ile mektuplar ve yazışmalarda kullanılan dil, yanıt verme süresi gibi örnekler kontrol edilemeyen iletişime girmektedir. Diğer taraftan genel anlamda kurumsal iletişim kontrol edilebilir bir özelliğe sahiptir. Belirli kuralları oluşturulmuștur ve o kurallar üzerinden hedef kitleye mesajlar aktarılmaktadır (Melewar, 2003: 184-186).

Esasında kurumsal kimliğin ana unsurları olarak değerlendirilen kurumsal tasarım, kurumsal kültür ve kurumsal davranış bir anlamda kurumsal iletişim üzerinden yansıma bulmakta, iç ve dış hedef kitleye ulaştırılabilmektedir. Dolayısıyla uzun dönemli ve planlı olarak kurgulanmış kurumsal iletişim çalışmaları ister yönetici temelinde kurulan yönetim iletişimi, ister pazarlama iletişimi (satış, promosyon vb.), isterse kurumun ilişkide bulunduğu tüm paydaşlarla iletişim olsun bütüncül şekilde kurum kimliğini ortaya koymaktadır. Bu durum yazılı, görsel ve dijital materyallerle birlikte ilişkilerin aktarılması şeklinde de pratiğe yansımaktadır. Kısaca kurumsal iletişimi, temelde amaçlarını gerçekleştirmek üzere kurumların kendini iç ve dış hedef kitleye ifade etmesi ve onlardan geribildirim alarak ya da onlarla işbirliği içine girerek kurumu yeniden kurgulaması şeklinde ifade etmek mümkündür.

\title{
1.4. Kurumsal Davranıș
}

Bireylerin nasıl kendine özgü davranışları bulunmaktaysa kurumların da aynı şekilde çeşitli durumlar ve süreçlerde nasıl davrandığı önemsenmektedir. Aradaki temel fark, bireysel davranışlar kişisel bir boyutta iken kurumsal davranış tüm kurumu çalışanlarıyla birlikte kapsamakta, yani grupların genel olarak davranma şeklini göstermektedir. $\mathrm{Bu}$ durumda kurumsal davranış, bireylerin davranışlarının toplamından çok kurum üyelerinin aynı konuda verdiği ortak refleks ve bakış açısını ifade etmektedir. Diğer bir farklııı da kurumun çalışanlarına yalnızca bir ekonomik getiri sağlayan araç olarak bakması değil, onları psikolojik ve sosyal intiyaçları olan değerli varlıklar olarak görme ve amaçlarına ulaşmaları için onlara yardımcı olacak ortamın yaratılması şeklinde ortaya çıkmaktadır (Oktay, 1996:266). Melewar'a (2003: 195) göre kurumsal davranış, "kurum kültürüyle aynı çizgide planlanan ya da kurumsal tutumlar sonucu kendiliğinden ortaya çıkan kurumsal eylemlerin toplamı"nı ifade etmektedir. Ludlow (1997: 88) ise kurumsal davranışın kesinlikle kurumsal kimliğin bir boyutu olduğuna 
dikkat çekmekte ve özellikle kriz dönemlerinde kurumsal davranışın (kurumsal ilişkiler, medya ilişkileri) kurumun paydaşlarının bakış açısını en az görsel kimlik kadar güçlü bir şekilde etkilediğini belirtmektedir (aktaran Melewar, 2003:195).

Okay (2013:181-184), Regenthal'den esinlenerek kurumsal davranış tarzlarını ekonomik davranış, toplumsal davranış, siyasal davranış, bilgilendirme davranışı ve kalite davranışı olarak belirlemektedir. Ekonomik davranış, kurumun ekonomik faaliyetler esnasında birey ve gruplara karşı sergilediği davranışlardır. Daha çok pazarlama odaklı gerçekleştirilen davranış şeklidir. Her kurumun ürettiği ürün ya da hizmetle ilgili piyasada ortaya koyduğu bir davranış şekli vardır. Gerek yurt içi gerekse yurt dışı piyasada aynı temel davranışları sergilemek ürün ve hizmetin pazarlanmasında kurumsal kimliği temsil eden bir öğe olarak görülmektedir. Diğer taraftan ürünün tasarımından satışına, konumlandırımasına, servis ve müşteri hizmetlerine kadar geniş bir perspektifte kurumun temel davranışları aynı bakış açısıyla gerçekleştirilmelidir. Kurumların toplumsal davranışları dendiğinde başlıca davranış noktaları olarak kurumun sosyal sorumluluk davranışı, ahlaki davranışı ve çevreye karşı duyarlıı̆̆ını ortaya koyduğu ekolojik davranışı akla gelmektedir. Kurumlar, bu davranışlarla yalnızca ekonomik bir yapılanma olmadığını, bunun ötesinde topluma karşı sorumluluklarının bilincinde olduğunu ve kazandıklarını toplumla paylaştığını göstermektedir. Siyasal davranıș, kurumların siyasal çevresinde yer alan kamu örgütleri, devlet, sermayedarlar, sendikalar, çeşitli dernek ve organizasyonlarla ilişkilerinde geliştirdiği davranış şeklidir. Kurumsal kimliği ifade eden diğer bir davranış şekli de bilgilendirme davranışıdır. Bilgilendirme davranışı, temelde kurumun iç ve dış hedef kitleye, doğru ve zamanında bilgi akışı sağlaması ve iletişim geliştirmesini göstermektedir. Kalite davranışı olarak ise ürün ve hizmetlerin hedef kitlenin memnuniyetine uygun ortaya konulması, bu bağlamda güvenlik, performans, uygunluk, dayanıklılık, servis kolaylığı, estetik ve uygun fiyatın ortaya konulmaya çalışıldığı davranış şekli olarak ifade edilebilir. Diğer bir deyişle bu kavramların hepsinin birlikteliğiyle oluşturulan toplam kalite yönetimi bakış açısıyla davranış sergilenmesidir. Bütün bu kurumsal davranış unsurları gerçekleştirilirken dış hedef kitleyle birlikte çalışanların da dikkate alınması gerekmektedir. Personelin maaş durumlarının adil bir şekilde düzenlenmesi, izinler, çalışma ortamının uygun olması vb. gibi noktalar bu bağlamda belirtilebilir.

Kurumsal davranışın temsili öncelikle yönetim tarafından gerçekleştirilirken çalışanların davranışları da kurumsal kimliğin oluşturulmasında önemli unsur olarak dikkat çekmektedir. Üst yönetimin gerçekleştirdiği eylem ve söylemleri kurumsal kimliğin temel olarak temsilini göstermektedir. Kurumsal kimlik oluşumunda çalışanlar da öncelikle kendilerini kurum içinde tanımlama yollarını oluşturduktan sonra diğer çalışanlarla birlikte dış hedef kitleye kurumsal davranış şekli olarak yansıtmaktadırlar (Melewar, 2003: 196).

Kısaca ifade etmek gerekirse artan rekabet koşulları içinde kurumların oluşturdukları davranış kodları, topluma yardımcı olan, onlarla birlikte hareket eden, memnuniyet ve kalite ilkesine dayalı bir anlayıştan hareketle oluşturulmakta ve kurumsal kimliğin önemli aktarım sürecini ortaya koymaktadır. 


\section{Kurumsal Kimliğin Aktarım Aracı Olarak Web Siteleri}

Kurumsal kimlik, ana hatlarıyla ele alındığında bir kurumun ne yaptığını, ne yapmak istediğini, ne olduğunu ve gelecekte nerede olmak istediğini bütüncül olarak ortaya koymasıdır. Bu bağlamda kurumsal kimliğin çeşitli araçlar yoluyla aktarılması zorunludur. Yani kurumsal kimliğin oluşturulmasından aktarımına kadar geçen her basamakta iletişim söz konusudur. Kurumlar geçtiğimiz yüzyılda kurumsal kimlik özelliklerini dergi, kurum içi gazete, bülten, afiş, broşür, gazetelerde yer alma, sergilere ve fuarlara katılma gibi araçlarla sağlamaktaydılar. Bu araçlar, temelde aslında tek yönlü iletişim olgusunu ön planda tutmaktadır. Başta küreselleşme ve bilgi toplumunun getirdiği dönüşümle birlikte bilgi akışını hızlandıran ve anlık iletişimi sağlayan iletişim teknolojisinin gelişmesi ile ortaya çıkan internet, bilgi akışının yönünü neredeyse tamamen değiştirmiştir. İnternet teknolojisinin kullanılmaya başlandığı 20. yüzyılın son yıllarında kurumlar da rekabetin getirdiği zorunluluk nedeniyle kendilerini daha iyi ifade edebilmek ve hedef kitleye ürün ve hizmetlerini daha hızlı tanıtıp sunabilmek için kendilerine ait web siteleri oluşturmaya başlamışlardır. Web 1.0 ile başlayan internet kullanımı kurumların yalnızca kendilerini ifade etmelerine dayanmakla birlikte web 2.0 teknolojisi karşılıklı iletişimi mümkün kılan interaktif bir uygulamayı beraberinde getirmiştir. Web 2.0 teknolojisi kullanıcılara verileri kontrol etme ve müdahale olanağı sunarken, tasarım açısından zengin, etkileşimli, kullanıcıya kolaylık sağlayan ara yüzlerden oluşmaktadır. Bununla birlikte gelişen sosyal ağlar veya yeni medya olarak adlandırılan uygulamalar tümüyle anlık iletişimi mümkün kılmaktadır (Budak ve Budak, 2014: 307-310). Bu durum, başta halkla ilişkiler olmak üzere pazarlama iletişimi açısından da simetrik iletişimi sağlaması noktasında önem kazanmıştır. Nitekim, internetin çift yönlü iletişim ortamı sağlaması, kurumlar için hızlı geribildirim elde etme ve ona uygun konum belirlemesine imkan tanımıştır (Uzunoğlu vd., 2009: 37).

İnternette yayınlanan bir bilginin anında dünyanın herhangi bir bölgesine ulaşıyor olması kurumların bu iletişim aracını kullanmasını gerektirmiştir. Belki de hiç karşılaşmayacağı bir işletme ile ilgili bilgi almak isteyen insanlar o işletmenin sattığı ürün ve hizmetlerden anında haberdar olabilmektedir. Bu durum, kurumların kendi web sayfalarını oluşturarak bir sistem üzerinden kendini hedef kitleye anlatma, satış yapma, müşteriyle sanal iletişime geçme ve onların beklentilerini çeşitli anketlerle elde edebilmesine olanak sağlamıştır. Böylece iletişim kişiselleştirilmiş, hazırlanan içeriklere zaman, mekan ve medya ortamı kısıtlaması olmadan ulaşılabilir hale gelinmiştir.

İster özel sektör, kamu sektörü isterse bir siyasal parti olsun tüm kurumların, gerçekleştirmek istediklerini ve kim olduğunu interneti verimli kullanarak hedef kitlesine ulaştırabilmesi mekan sınırı olmadan gerçekleşmeye başlamıştır. Buradan hareketle kurumların kendine dair bilgiler, kurumsal işleyiş ve toplumsal bakışını ifade edebilmesinin yanı sıra gerektiğinde bu bilgi ve uygulamaları dinamik tutarak beklentilere uygun hale getirmesi mümkün olmaktadır. Yaşayan her kurum doğal olarak böylesine hızlı, mekan ve zaman sınırı tanımayan iletişim aracını kullanmak ve etkin bir yapıya sahip olmak isteyecektir. Bu bağlamda hareketli, görsel olarak iyi düzenlenmiş, kullanıcının rahat ulaşabileceği ara yüzlerle kurgulanmış web sitelerinin yapılması tüm kurumlar için temel gereklilik halini almıştır.

Kimi örgütler sektörüne uygun olarak yalnızca satış ve pazarlama ağırlıklı bir web sitesi uygulamasına gidebileceği gibi doğrudan kar amacı gütmeyen kurumlar da kurumsal 
kimliğini belirgin nitelikleriyle aktarmak ve sonuçta kurumsal imajını yükseltmek hedefini gütmektedir. Söz konusu süreç, bu çalışmanın kapsamı açısından değerlendirildiğinde siyasal partiler için web siteleri seçmen kitlesine ulaşmanın en hızlı, pratik ve ekonomik bir aracı olarak ön plana çıkmaktadır. Siyasal partiler, basılı veya görsel medyadaki gibi arada hiçbir eşik bekçisi olmadan seçmen kitlesi ile dijital ortamda iletişim kurabilmektedirler. Partinin kurumsal yapısından liderin konuşmalarına kadar anında seçmen kitleye bilgi aktarımı mümkün olabilmekte, seçmenlerin bireysel olarak düşüncelerini yansıtan e-mail gibi iletişim olanaklarıyla nabızlarını tutabilmektedirler. $\mathrm{Bu}$ anlamda diğer kurumlarda olduğu gibi siyasal partilerde de web sitelerinin doğru değerlendirilmesi halinde iyi bir simetrik iletişimin oluşturulabileceği varsayılabilir.

\section{Araștırmanın Yöntemi}

Bu çalışmanın amacı Türkiye'deki siyasal partilerin kurumsal kimlik çalışmalarının web siteleri üzerinden nasıl yansıtıldığını analiz ederek ortaya koymaktır. Araştırmanın evreni Türkiye'de örgütlenmiş siyasal partiler, örneklemi Türkiye Büyük Millet Meclisi'nde (TBMM) temsil edilen dört siyasal partidir. Türkiye çapında örgütlü 97 siyasal parti (www.yargitaycb.gov.tr) yer almasına karşılık 1 Kasım 2015 seçimlerinde TBMM'de temsil edilen dört siyasal partinin ele alınması çalışmanın sınırlılığını oluşturmaktadır. Ancak ele alınan bu dört parti olan Adalet ve Kalkınma Partisi (AKP), Cumhuriyet Halk Partisi (CHP), Halkların Demokratik Partisi (HDP) ve Milliyetçi Hareket Partisi (MHP) seçmen kitlesinin toplamda tüm seçmenlerin \%97.5'ini (www.ysk.gov.tr) temsil ettiği sonucuna göre örneklemin Türkiye genelini büyük oranda yansıttığı söylenebilir. Araştırmanın dört temel sorusu bulunmaktadır:

- Siyasal partiler, kurumların temel görsel unsurları olan logo ve renklerin kullanımı, fotoğraf-yazı dengesi gibi öğelere dayanan kurumsal tasarım çalışmasını web sitelerine doğru bir şekilde yansıtabilmişler midir?

- Kurumsal kimlik uygulamalarının hedef kitleye aktarılmasını sağlayan araç olarak kurumsal iletişim olgusu, parti web sitelerinde nasıl yer almaktadır?

- Değerler, normlar, varsayımlar, adetler, mitler, semboller ve kahramanların hedef kitleye aktarılması şeklinde gerçekleşen kurumsal kültür öğeleri parti web sitelerinde ne şekilde yer almaktadır?

- Kurumsal kimlik öğesi olan kurumsal davranış unsurları siyasal partilerin web sitelerinde ne düzeyde yansıtılmaktadır?

Araştırmada söz konusu siyasal partilerin web siteleri, kurumsal kimlik öğeleri ile ilgili Değerlendirme Ölçeği Formu oluşturularak içerik analizi yöntemiyle değerlendirmeye alınmıştır. Bu kapsamda partilerin web siteleri 22-28 Şubat 2016 tarihleri arasında bir hafta incelemeye alınarak Değerlendirme Ölçeği Formuna kodlama yapılmıştır. Kodlamalarda siyasal partilerin web sitelerinde kurumsal tasarım, kurumsal iletişim, kurumsal davranış ve kurumsal kültüre ilişkin verileri ne şekilde kullandıkları sorgulanmaktadır. Buradan hareketle elde edilen bulgularla siyasal partilerde kurumsal kimlik çalışmalarının web sitelerine nasıl yansıdığı ortaya konulmaya çalışıımaktadır. 


\subsection{Kurumsal Tasarımın Web Sitelerine Yansımasına İlișkin Bulgular}

Siyasal aktörler interneti iki amaçla kullanmaktadırlar. Bunlardan ilki, amaçlarını gerçekleştirmek ve kendilerini tanıtmak, bu anlamda haber ve bilgi akışı sağlamaktır. Diğeri ise öteki siyasal aktörlerin mesajlarını takip etmek ve onlar hakkında bilgi almaktır (Aziz, 2007: 63). Bu amaçların ilki genelde daha ağırlıklı olarak ön plana çıkmaktadır. Partilerin kendilerini tanıtabilmek ve seçmen kitleyi ikna edebilmek için öncelikle kurumsal tasarımı web sayfaları üzerinden doğru bir şekilde aktarabilmelerine bağlıdır. Kurumsal tasarım çalışması, web sayfaları örneği üzerinden düşünüldüğünde logonun kullanımından haberlerin sayfada yerleştirilmesine, kurumsal renklere uygun sayfa düzenlemesine, sitedeki kategori sayısına (ana sayfadan tıklandığında girilebilen linkler), fotoğraf ve yazı dengesine, sayfadaki video sunumlarına ve daha da önemlisi sayfanın genel anlamda karmaşık olup olmadığına ilişkin geniş bir alanı kapsamaktadır. Bütün bunlar site ziyaretçilerinin o sayfada kalmayı sürdürme veya çıkma dürtülerini etkileyecektir. Kurumsal tasarıma ilişkin belirlenen bu özellikler Değerlendirme Ölçeği Formuna kodlanarak AKP, CHP, HDP ve MHP'nin web sayfaları analiz edilmiştir.

Tablo 1. Siyasal Partilerin Web Sitelerinde Kurumsal Tasarıma Illișkin Değerlendirme ölçeği Formu

\begin{tabular}{|l|l|l|l|l|}
\hline İșaretlemeler: + var,- yok, $\mathrm{x}$ yeterli değil & AKP & CHP & HDP & MHP \\
\hline Logo kullanımı & + & + & + & + \\
\hline Kurumsal renklere uygunluk & + & + & + & + \\
\hline Kurumsal yazı karakterine uygunluk & + & + & + & + \\
\hline Zemin rengi & Beyaz & beyaz & beyaz & beyaz \\
\hline Rahat okunabilirlik & + & + & + & + \\
\hline Fotoğraf, video vb. görseller & + & X & + & x \\
\hline Sayfa uzunluğu & + & + & + & x \\
\hline Sayfa kenar boșluğu & + & + & + & + \\
\hline Fotoğraf yazı dengesi & + & + & + & + \\
\hline Sayfanın karmașıklı̆ı & + & - & - & - \\
\hline Farklı diller seçeneği & - & - & + & + \\
\hline Farklı kategorilere geçiș kolaylı̆ı & + & + & + & + \\
\hline
\end{tabular}

Adalet ve Kalkınma Partisi: Değerlendirme Ölçeği Formunda kurumsal tasarıma ilişkin sorgulanan konu başlıklarına göre AKP'nin web sitesi (www.akparti.org.tr) ana sayfası değerlendirildiğinde olumlu olduğu gözlenmektedir. Ana sayfada kurumsal tasarımı yansıtan temel kavramlardan olan logo kullanımı bulunurken ayrıca okunabilir ve partinin kurumsal yazı karakterine uygun bir yazı fontu kullanılmıştır. Partinin web sitesi açıldığında ilk dikkat çeken özellik, kurumsal renkleri olan siyah, mavi ve turuncu rengin sayfanın tamamında yazı ve şeritlerde belirgin olmasıdır. Üst sol bölümde logonun hemen sağındaki şerit mavi renk zemin üzerine yazı ile belirginleştirilmiştir. Şeridin üst kısmında sağda partinin diğer web sitelerine verilen link turuncu renktedir. Üst bandın altında genelde web sitelerinde haber verme amaçlı kullanılan alanda genel başkanın iki etkinliğine ve partinin eylem planına yer verilmiştir. Bu alandaki 
görselin sağ ve sol marjlara tam olarak dayalı ve büyük bir alanı kapsaması nedeniyle algılamayı zorladığı varsayılabilir. Bu görselin altında sayfanın ikinci bölümü olarak ifade edilebilecek bölüm üç sütuna ayrılmıştır. Soldaki diğerlerine göre daha geniş olan sütunda parti yöneticilerinin etkinliklerine yer verilirken, ortada öncelikle sosyal ağlara link verildikten sonra alt kısımların tamamında genel başkan haberleri video ve fotoğraflı şekilde verilmektedir. Sağ bölümde ise genel başkanın günlük programına başlıklarla link verildikten sonra hemen altında ulusal basında çıkan haberler "Medyada AK Parti" olarak konumlandırımış, hemen altında ise genel başkanın konuşma metinlerinin linkleri yer almıştır. Sağ sütunun alt bölümlerinin tamamında önemli icraatlar, hedefler ve projeler fotoğraflı başlıklarla sunulmuştur. Bu üç sütunun üstünde "icraatlar" başlığında yapılan çalışmalar yer alırken sağ sütunda aşağıya doğru yine "icraatlar" başlığıyla yeni başlatılacak projelere vurgu yapılmaktadır. Sayfanın en alt kısmında ise e-posta, AKBiS, Kütüphane ve Siyaset Akademisi linklerine beyaz zemin üzerinde yer verilmiştir.

Genel olarak bakıldığında, ana sayfada zemin rengi olarak beyaz hakimdir. Yazı karakteri kurumsal yapıya uygun ve rahat okunabilir şekilde verilmiştir. Sayfada algılamayı artırıcı öğeler olarak görsellere yazıyla dengeli bir şekilde yer verilmiştir. İngilizce ve Arapça dil seçeneği bulunmakta ve ilgili linklerin altında Türkçe sayfayla hemen hemen aynı tasarımın yer aldığı gözlenmektedir. Ayrıca farklı kategorilere geçişte sıkıntı yaşanmamaktadır.

Cumhuriyet Halk Partisi: Değerlendirme Ölçeği Formunda kurumsal tasarıma ilişkin sorgulanan konu başlıklarına göre CHP'nin web sitesi (www.chp.org.tr) ana sayfası analiz edildiğinde sorgulanan başlıkların büyük bölümünde olumlu bulgular elde edilmiştir. Ana sayfada kurumsal tasarımı yansıtan temel kavramlardan olan logo kullanımı bulunurken ayrıca okunabilir ve partinin kurumsal yazı karakterine uygun bir yazı karakteri kullanılmıştır. Sayfada zemin rengi olarak beyaz hakim olmakla birlikte sağ ve sol kenar boşluklarında partinin kurucusu olan Mustafa Kemal Atatürk ve bugünkü genel başkanın fotoğrafları zeminde gri renkte verilmektedir. Ana sayfada logo şeridinin alt bölümündeki menülerde ağırlıklı olarak haber ve medya ilişkilerini kapsayan başlıklar yer almaktadır. Hemen altında biri diğer ikisinden daha büyük olan üç ayrı haber görseli yer almaktadır. Soldaki ilk büyük bölümde genel başkanın etkinliklerine ait görsel yer alırken sağdaki üst üste iki görselde partinin genel başkan dışındaki örgüt üyeleri tarafından yaptıkları güncel etkinliklerin haberleri verilmektedir. Partiye üyelik çağrısını içeren tüm yatay ekseni kapsayan şeridin altında üç sütun oluşturularak soldaki ilk sütunda milletvekili haberleri, yerel yönetim etkinlikleri, medya albümü ve diğer daha eski haberlere yer verilmektedir. Sağ dikey sütunda ise genel başkanın sosyal medya ağından yayınladığı mesajlar aktarılmaktadır. Sayfanın en alt kısmında da partinin tamamlayıcı kurumsal rengi olan siyah zeminde parti organları ve diğer bilgilerle ilgili linkler verilmektedir.Öte yandan diğer partilerin aksine CHP web sitesinde Türkçe dışında herhangi bir dilde sayfa tasarımı bulunmamaktadır.

CHP web sitesi ana sayfasında fotoğraflar kullanılmakla birlikte doğrudan hiçbir video uygulamasına yer verilmemiştir. Bu tür görsel-işitsel uygulamalar, sosyal medya ve CHP TV'ye sayfanın en üstünde logonun yer aldığı șeritte link verilmiștir. Ancak CHP TV bağlantısının aktif olmadığı görülmektedir. Genel başkanın twitter mesajları sağ şeritte başlı başına bir bölüm olarak verilmiştir. 
CHP'nin web sitesi ana sayfası tümüyle değerlendirildiğinde, logo, kurumsal yazı karakteri ve parti renklerinin sayfada aktif olarak kullanıldığı, yazıların rahat okunabilir olduğu bulgulanmıştır. Zeminde beyaz rengin hakim olduğu, sayfa uzunluğu ve fotoğraf yazı dengesinin sağlandığı görülmektedir. Ancak ana sayfada video uygulamalarına yer verilmediği ve dil seçeneği olarak Türkçe dışında herhangi bir dilin yer almadığı dikkat çekmektedir.

Halkların Demokratik Partisi: Ana sayfada parti logosunun yer aldığı, kurumsal yazı karakteri ve kurumsal renklere uygun bir tasarım yapıldığı gözlenmektedir. Zeminde beyaz renk yer alırken sayfa genelinde partinin kurumsal rengi olarak hakim rengin mor olduğu bulgulanmıştır. Logo, sayfanın üst köşesinde yer almakta sağ karşısında ise basın açıklamalarına yer verilmektedir. Bu bandın üzerinde sosyal medya linkleri bulunmaktadır. Buna göre partinin sosyal medyayı ve basını önemsediği ve mesajlarını öncelikle bu araçlar üzerinden vermek istediği söylenebilir. Ana bölümde parti haberlerinin yer aldığı soldan sağa uzanan tüm alanı kaplayan bölümde parti eş genel başkanları ve üyeleriyle ilgili bilgi akışı bulunmaktadır. Sayfanın kalan alt bölümünün tamamı ikiye ayrılmış, ilkinde üstte verilen haberlerin tekrarlarıyla birlikte başka haberlere yer verilmiştir. Sağda yer alan ikinci sütunda ise alt alta tekzipler, meclis çalışmaları ve basın açıklamalarına ait anons başlıklar büyük harflerle ve kurumsal renklerle vurgulandıktan sonra hemen altında eş genel başkanların twitter ve Instagram paylaşımları yer almaktadır. Sayfada ayrıca üst kısımda verilen linkler dışında en altta siyah zemin üzerinde eş genel başkanların Youtube ve Instagram paylaşımları doğrudan kullanılmaktadır.

Sayfada yazı-fotoğraf dengesinin sağlandığı, karmaşıklığın olmadığı, uygun kenar boşluklarının verildiği bulgulanmıştır. Fotoğraflarla birlikte video ve sosyal medya uygulamalarına yer verilmesi, partinin bu uygulamalara önem verdiğini göstermektedir. Öte yandan Türkçe dışında İngilizce web sayfasına da yer verilerek uluslararası hedef kitleyi kucaklama mesajının olduğunu söylemek mümkündür. Ancak İngilizce web sayfa tasarımının ana sayfa tasarımından faklı olarak kurgulandığı, adeta bir dergi web sayfasını andırdığı, görselliğin zayıf olduğu gözlenmektedir.

Milliyetçi Hareket Partisi: Değerlendirme Ölçeği Formunda kurumsal tasarıma ilişkin sorgulanan konu başlıklarına göre MHP'nin web sitesi (www.mhp.org.tr) ana sayfası analiz edildiğinde sorgulanan başlıkların büyük bölümünde olumlu bulgular elde edilmekle birlikte yetersiz olan alanların bulunduğu dikkati çekmektedir. Ana sayfada kurumsal tasarımı yansıtan temel kavramlardan olan logo kullanımı bulunurken ayrıca okunabilir ve partinin kurumsal yazı karakterine uygun bir yazı karakteri kullanılmıştır.

Web sitesine girişte üst ortada logo yer alırken hemen altında parti kurumsal rengi olan kırmızı renkteki şeritte partinin yapısıyla ilgili menüler bulunmaktadır. Ana bölümde ise diğer partilerdekinin aksine soldan sağa uzun ve büyük şeritte haberlerin yerine parti genel başkanın sözlerinin ve MHP'nin ilk liderinin görsellerinin yer aldığı görülmektedir. Hemen altında yine tamamen genel başkanın fotoğraf ve etkinliklerinin yer aldığı üç sütunluk bölümün sağında parti üyelerinin yaptığı basın açıklamaları sunulmaktadır. Bu bölümün alt kısmında partiyle bağlantılı web sitelerinin linkleri verilirken, sayfanın en alt kısmındaki kırmızı şeritle sayfa tamamlanmaktadır. Ayrıca logonun bulunduğu şeridin üstünde solda Türkçe-İngilizce web sitesi ile sağda sosyal medya ağlarına bağlantı verilmektedir. Web sitesi ana sayfasında doğrudan hiçbir video veya sosyal medya uygulamasına yer verilmemektedir. 
Genel olarak değerlendirildiğinde, MHP web sitesinin kurumsal renklere uygun tasarımının yapıldığı gözlenirken, video uygulamalarına yer verilmediği dikkat çekmektedir. Ayrıca haber tasarımlarında genel başkan dışında hiçbir parti üyesinin fotoğrafının yer almadığı görülmektedir. Sayfa kenar boşlukları bulunmakla birlikte sayfa uzunluğunun yeterli olmadığı görülmektedir. Zemin rengi beyazdır. Sade bir tasarım uygulamasıyla sayfada karmaşıklığa yer verilmemekte, farklı linklere geçişte sorun yaşanmamaktadır. Ayrıca sayfada farklı dil seçeneği olarak İngilizce linki yer almaktadır.

\subsection{Kurumsal Kültürün Web Sitelerine Yansımasına Ilișkin Bulgular}

Demokratik sistemin önemli kurumlarından biri olan siyasal partilerin de diğer kurumlarda olduğu gibi kurumsal kültürü geliştirmeleri, kendilerini hedef kitlelerine doğru ifade edebilmeleri açısından önemlidir. Hedeflerinin iktidara gelme düşüncesi olduğundan hareketle partilerin bu hedefe ulaşabilme adına güçlü bir kurumsal kültür yapısını oluşturarak iç ve dış hedef kitleye mesajlarını iletebilmeleri esastır. Partilerin bu çabalarını iletişim teknolojisinin yoğunlaştığı son yıllarda diğer etkinliklerin yanı sıra özellikle internet üzerinden de sağlamaya başladıkları görülmektedir. Bu bağlamda partilerin doğru kurgulanmış web siteleri, kurumsal kültürün unsurları olan değerler, normlar, varsayımlar, adetler, mitler, semboller ve kahramanların hedef kitleye aktarılmasında önemli katkı sağlamaktadır. Siyasal partiler, bu kapsamda kurumsal kültürü web sitelerinde yer verdikleri amaçlar, hedefler, vizyon, misyon, parti programları, parti tarihi, partinin kurucu genel başkanları, seçim beyannameleri, semboller ve kendini konumlandırdığı yerin ifade edilmesi gibi başlıklar altında ortaya koymaktadırlar.

Tablo 2. Siyasal Partilerin Web Sitelerinde Kurumsal Kültüre Illișkin Değerlendirme Ölçeği Formu

\begin{tabular}{|l|l|l|l|l|}
\hline İșaretlemeler: + var,- yok, $x$ yeterli değil & AKP & CHP & HDP & MHP \\
\hline Temel değerler lamaç, hedef, vizyon, misyon) & + & + & $x$ & + \\
\hline Parti programları & + & + & + & + \\
\hline Parti tarihi & - & + & - & + \\
\hline Kurucu genel bașkanlar & - & + & - & + \\
\hline Seçim beyannameleri & + & + & + & + \\
\hline Liderler, kahramanlar & - & + & - & + \\
\hline Ritüeller & - & - & - & - \\
\hline Dil & + & + & + & + \\
\hline Semboller & - & + & - & - \\
\hline Varsayımlar & - & - & - & - \\
\hline
\end{tabular}

AKP'nin kuruluşundan itibaren kendini konumlandırdığı "akparti” imajı web sitesinde de yansıma bulmakta ve sayfaya www.akparti.org.tr olarak girilebilmektir. Partinin kurumsal amaç ve hedeflerini ana sayfada "Parti" başlığı altında yer alan parti tüzüğü, parti yönetmelikleri, parti programı, seçim beyannameleri, 2023 siyasi vizyon, icraatlar ve hedef 2023 alt başlıklarında bulmak mümkündür. Parti tüzüğü, parti yönetmelikleri 
yasal bir arka planı oluştururken parti programı ve özellikle 2023 hedefinin konulması partinin geleceğe yönelik vizyonunu işaret etmektedir. Bu kapsamda aktarılan bilgilerin hemen her alanda ayrı ayrı sınıflandırılarak anlatıldığı bulgulanmıştır. Yine hükümetin eylem planının ana sayfada vurgulanarak verildiği görülmektedir. Tüm bu başlıklar altında yer alan bilgilerde hem partinin amaç, vizyon ve misyonu hem de geleceğe dönük hedeflerine yönelik bilgiler verilmektedir. Ancak web sayfasında partinin tarihi geçmişi ile parti geçmişinde önemli rol üstlenen kişilikler yer almamaktadır. Bu anlamda yalnızca bir başlık altında parti kurucularının kısa özgeçmişlerine yer verilmiştir. Diğer bir deyişle, temelde parti kurucusunun kahramanlaştırılarak aktarılması durumu görünür değildir. Ölçekte sorgulanan bir konu olan dilin kullanımı, sunulan dokümanlarda AKP'ye uygun bir şekilde kodlanmaktadır. Ayrıca ana sayfada semboller, varsayımlar ve ritüellere ilişkin bir bulguya rastlanmamıştır.

CHP'nin web sitesine girildiği anda parti kurucusu olan Atatürk vurgusu görsellerde dikkat çektiği gibi “CHP” linkinin altında CHP'nin kuruluşundan bugüne geçirdiği evreler anlatılmaktadır. Aynı başıı altında parti programı, tüzüğü, yönetmelikleri ve seçim bildirgeleri ayrı ayrı anlatılmaktadır. Bu anlatımlarda partinin sembolü olan altı okun anlamına vurgu yapılmakta ve CHP'nin Atatürk ilkeleri ıșığında bugünkü atmak istediği adımlara dair mesajlar verilmektedir. Parti ile ilgili aktarılan bilgilerin 2007 yılına kadar verildiği ve o tarihten itibaren bir bilgi eklenmediği görülmektedir. Parti programında da Atatürk ilkelerine vurgu yapıldıktan sonra partinin yeniden yapılanması ile ilgili mesajlar verilerek "Çağdaş Türkiye İçin Yeniden Değişim Programı" adıyla bu durum kavramsallaştırımaktadır. Diğer yandan partinin çıkardığı yayınlar başlığı altında "Parti Meclisi Raporları", "Ekonomik Görünüm Raporları", "Bilim Platformu Yayınları" gibi başlıklar altında partinin geleceğe yönelik mesajları yer almaktadır. Ana sayfada ritüeller ve varsayımlara ilişkin herhangi bir bulguya rastlanmamıştır.

HDP'nin kurumsal kültür yaklaşımına bakıldığında ana sayfada yer alan "Parti” başlığı altındaki alt başlıklarda parti tüzüğü ve parti programının yer aldığı ve programda partinin hedef ve vizyonuna ilişkin bilgilerin aktarıldığı görülmektedir. Ancak genel bir yaklaşımla bakıldığında, HDP web sitesinde partinin tarihi, kurucuları, misyonu, vizyonu ve hedeflerine ilişkin açık bir bilgilendirmenin olmadığı görülmektedir. Ana sayfada yer alan "Materyaller" başlığı altında da kurumsal kimlik çalışması ve farklı dönemlerde yapılan seçim çalışmalarına ilişkin dokümanlar yer almaktadır. Yapılan analizle HDP'nin parti ile ilgili materyallerinde partiye uygun dil kullandığı bulgulanırken, kahramanlar, ritüeller, semboller ve varsayımlarla ilgili bulguya rastlanmamıştır.

MHP'de web sayfasına girişte yer alan "Başbuğ" adlı linkte partinin ilk genel başkanı Alparslan Türkeş'in hayatı, fotoğrafları, özlü sözleri gibi bilgilere geniş bir şekilde yer verildiği görülmektedir. Bu bağlamda parti tarihine ilişkin de bilgiler aktarıldığını söylemek mümkündür. Aynı sayfada genel başkana ayrı bir bölüm ayrılarak genel başkanın hayatı, fotoğrafları ve yayınlarıyla ilgili bilgiler sunulmuştur. Ayrıca sayfada kullanılan ilk büyük görselde hem ilk genel başkan hem de bugünkü genel başkanın fotoğraf ve sözleri ön plana çıkarılmaktadır. Partinin kurumsal kültürünü yansıtan diğer öğeler olarak partinin tüzük, program ve seçim beyannamelerini "Milliyetçi Hareket Partisi” başlığı altında görmek mümkündür. Ayrıca 2011 yılı seçim beyannamesinde yer alan "2023'e Doğru Türkiye Sözleşmesi”nde partinin vizyonu, hedef ve görüşleri ile vaatlerinin yer aldığı görülmektedir. Ancak genel olarak bakıldığında seçim beyannamesi dışında partiye ilişkin misyon, vizyon ve hedefler konusunda ayrı bir 
başlık altında herhangi bir çalışmanın olmadığını söylemek mümkündür. Sayfada sunulan materyallerde partiye uygun dil kullanılırken partiye ilişkin ritüel, sembol ve varsayımlarla ilgili bulguya rastlanmamıştır.

Özetle ifade etmek gerekirse partilerin kurumsal kültüre ilişkin değerlendirmelerini seçim beyannamelerinde ve parti programlarında görmek mümkündür. Ayrıca çeşitli yayınlarla bu yönde çalışmaların gerçekleştirildiği gözlenmektedir. Diğer taraftan CHP dışında hiçbir partinin, tarihi geçmişi ve temel ilkeleri konusunda açık bilgiye rastlanmamakta, CHP ve MHP dışında kurucu genel başkanlarla ilgili herhangi bir bilgiye yer verilmemektedir.

\subsection{Kurumsal İletișimin Web Sitelerine Yansımasına Illișkin Bulgular}

Kurumsal kimliğin tüm süreçlerinin hedef kitleye yansıtılması temelde kurumsal iletişim olgusu üzerinden gerçekleşmektedir. Siyasal partiler bu bağlamda gazete, bülten, dergi, TV, internet uygulamaları gibi yazıll-görsel-işitsel ve dijital materyallerden yararlanabileceği gibi yüz yüze iletişim sağlayarak da kurum kimliğini hedef kitleye aktarabilmektedirler. Geniş bir alanı kapsayan kurumsal iletişim, yalnızca bu çalışmanın kapsamı açısından değerlendirildiğinde bile web sayfaları ortamında yer alan tüm haberler, genel başkanın konuşmaları, kurumsal kimliğe ait farklı unsurlarla ilgili bilgi akışının sağlanması, kullanılan fotoğraflar, tüzükler, genelgeler, elektronik yayınlar, tekzipler, online parti iletişim sayfaları, webTV, e-posta, sosyal medya ve videolar gibi birçok alanın bu bağlamda değerlendirilebileceği açıktır. Öte yandan kurumsal iletişimi bir partinin hem iç hem de dış hedef kitlesiyle kurduğu tüm iletişim çabaları olarak sınıflandırmak mümkündür. Buradan hareketle kapsamı sınırlı tutabilmek için siyasal partilerin kurumsal iletişimini web sitelerinde kullandığı araçlar üzerinden okumanın daha uygun olacağı düşünülmektedir. Tablo 3'te buna ilişkin oluşturulan değerlendirme ölçeğine yönelik kodlamalar oluşturularak analiz edilmektedir.

Tablo 3. Siyasal Partilerin Web Sitelerinde Kurumsal İletișime İlișkin Değerlendirme Ölçeği Formu

\begin{tabular}{|l|l|l|l|l|}
\hline İșaretlemeler: + var,- yok, x yeterli değil & AKP & CHP & HDP & MHP \\
\hline Haberler & + & + & + & + \\
\hline Sosyal medya & + & + & + & + \\
\hline İletișim merkezi uygulaması & + & + & - & + \\
\hline Yayınlar & + & + & + & + \\
\hline TV yayını linki & - & + & - & $x$ \\
\hline e-posta & + & + & + & + \\
\hline İletișim adres ve telefon bilgisi & + & + & $x$ & + \\
\hline Medya arșivi (fotoğraf ve video albümü vb.) & + & + & $x$ & + \\
\hline Kurum içi iletișim & + & + & - & + \\
\hline
\end{tabular}

AKP'nin web sitesine bakıldığında ana sayfada "Haberler" menüsü altında yer alan alt başlıklarda genel başkan ve parti içindeki bölüm başkanlıklarıyla ilgili haberler ve foto-video galeri bölümünde geçmişten bugüne kadarki seçim dönemlerindeki 
mitingler dahil tüm çalışmaların bilgi akışı ayrıntılı şekilde verilmektedir. Aynı sayfada yer alan anonslarda parti adına geliştirilen twitter, facebook ve youtube paylaşımları gözlenmektedir. "Basın Odası" başlığı altında konuşma metinleri yer alırken sayfanın ana bandında kısa adı AKIM olan Ak Parti İletişim Merkezi uygulamasına ait link bulunmaktadır. AKIM kanalıyla farklı başıklar altında alınan yazılı soruların ilgili birimlere iletilerek yanıtlandığı belirtilmektedir. Ana sayfanın en altında yer alan e-posta ve AKBiS üzerinden parti üyeleri bilgilendirilmektedir. Sayfanın en üst sağ köşesinde yer alan "Diğer Resmi Ak Siteler" başlığı altında parti adına elektronik ortama konulmuş "Türkiye Bülteni” görülmektedir. Bültende parti etkinlikleri ve haberler verilmektedir. Ayrıca partiyle iletişim kurulabilmesi için oluşturulan "Bize Ulaşın" başlığı altında adres ve iletişim bilgileri yer alırken partinin il örgütlerinin telefon numaraları da verilmektedir. Ayrıca ana sayfada öncelikle medya kuruluşlarının bilgilendirilmesi hedeflenmiş, bunun dışında tüm hedef kitleyi esas alan bir iletişim uygulaması kurgulanmıştır. Bu bağlamda Ak Parti Bilgi Sistemleri (AKBiS)ve e-posta seçeneği ile de parti üyeleriyle ayrıca iletişim sağlanmaktadır. Diğer taraftan doğrudan ön planda olmamakla birlikte sosyal medya ağlarının da önemsendiği ana sayfada verilen bağlantılarla gözlenmektedir. Sorgulanan başııklar arasında yer alan TV yayını linki AKP web sitesinde bulunmamaktadır.

CHP'nin web sitesi analiz edildiğinde, ana sayfanın başında sağda yer alan sosyal medya ağlarına ait linklerden sonra ana menülerde "Haberler", "Yayınlar", "Medya" ve "Iletişim" başlıklarıyla bilgi akışının sağlandığı görülmektedir. "Haberler" menüsü içinde parti örgütlerinden bilgi akışı sağlanırken sayfada yer alan e-posta ile tüm seçmenlerin yorum yapabilmesine olanak tanınmıştır. "Yayınlar" başlığı altında partinin farklı komisyonları tarafından hazırlanan rapor ve çalışmalar yer almaktadır. "Medya" linki altında "Albümler" başlığıyla yer alan bölümde genel başkanın etkinlikleri sunulmaktadır. Yine aynı kısımda "CHP TV" başlığının yer aldığı, ancak halka açık herhangi bir içeriğin sunulmadığı görülmektedir. "lletişim” menüsünde genel merkez ve illere ilişkin adres ve telefon bilgileri yer alırken aynı sayfanın sağında halka açık mesaj gönderimini sağlamak için bir alan bulunmaktadır. Ana sayfanın ortasında geniş bir bantla verilen chp.net linkiyle haber ve içeriklere yorum yapabilme, parti üyeliğiyle ilgili hizmetlerden yararlanabilme, parti içi gelişmelerden haberdar olma ve partiye haber ve içerik yollamanın yolu açılmaktadır. Böylece iki yönlü iletişime dayalı bir yapının oluşturulduğu söylenebilir. Ayrıca ana sayfada genel başkanın twitter paylaşımlarının yer alması da diğer sosyal medya linkleriyle birlikte düşünüldüğünde parti tarafından dijital ortamda hedef kitleyle iletişim kurmanın önemsendiği düşünülebilir. Buna göre CHP'nin haber akışı, yayınlar ve sosyal ağlarla parti içi ve parti dışındaki halkla iletişim kurmayı hedeflediği görülmektedir. Ayrıca mesaj gönderebilme, geribildirim sağlama adına sosyal ağlarla birlikte geliştirilen chp.net linki simetrik iletişimin uygulandığını işaret etmektedir.

Belirlenen Değerlendirme Ölçeği Formu doğrultusunda HDP'nin web sitesi analiz edildiğinde aktarılan haberler dışında sosyal ağların (özellikle twitter'in öncelendiği) ve basın açıklamaları ile tekziplere yer verildiği görülmektedir. Ana sayfanın sağ başında "Basın Açıklamaları" vurgusu dikkat çekerken sayfanın alt kısımlarında sağda yine "basın açıklamaları" ve "tekzipler" başlıkları verilmektedir. Bununla birlikte sayfanın başında yer alan menülerde "Basın" linkinde yine aynı bilgiler yer almaktadır. Ancak medya arşiv çalışması bulunmamaktadır. Ayrıca ana menülerde "Duyurular" bölümüne yer verilmiş olmasına karşın bu bölümdeki duyuru içeriğinin güncelliğini 
kaybetmiş olduğu görülmektedir. "Iletişim" linkinde ise yalnızca genel merkez, İstanbul il örgütü, Avrupa ve Amerika temsilciliğinin adres ve iletişim bilgilerine yer verilmekte il örgütleriyle ilgili iletişim bilgisi yer almamaktadır. Diğer taraftan ana sayfada kullanılan linkler ve veriler ışığında partinin twitter, Instagram ve youtube gibi iletişim ağlarını etkin kullandığı söylenebilir. TV yayın linki bulunmayan HDP'nin AKP ve CHP'de olduğu gibi parti üyeleriyle iletişimi sağlamak üzere kurgulanmış bir kurum içi iletişim ortamı da bulunmamaktadır.

MHP'nin web sitesi incelendiğinde ana sayfada sosyal ağlara ilişkin linkler dışında, "Medya" menüsü altında parti yayınları, basın kiti ve partililere ait linklerin yer aldığı görülmektedir. Bu bölümde ayrıca fotoğraflar ve MHP'nin resmi televizyonu olarak seçim döneminde kurulmuş olan ancak halen aktif olmayan Alp Türk TV linki bulunmaktadır. Partinin web posta, sms üyeliği, teşkilat genelgeleri ve üyelik başlıkları altında kurgulanan linkler üzerinden partili üyelerle iletişim kurduğu görülmektedir. MHP'nin basın açıklamaları ve haberlerle tüm hedef kitleye ulaşmaya çalıştığı gözlenirken yalnızca parti üyelerinin girebileceği linklerle parti içi iletişim hedeflenmektedir denilebilir. Ayrıca ana sayfanın altında partinin iletişim bilgileri dışında 444'lü çağrı merkezi ön plana çıkarılmaktadır. Genel bir değerlendirmeyle MHP'nin haber ve medya iletişimiyle genel hedef kitleyle iletişim kurarken başta teşkilat genelgeleri olmak üzere çeşitli üyelik linkleriyle parti içi iletişime daha fazla ağırlık verdiği söylenebilir.

\subsection{Kurumsal Davranıșın Web Sitelerine Yansımasına Ilișkin Bulgular}

Siyasal partilerin kurumsal davranışının parti üyelerinden daha çok liderler üzerinden görünür kılındığı söylenebilir. Çünkü partinin herhangi bir konuya bakışı ve verdiği tepki öncelikle liderler üzerinden temsil edilmektedir. Kuşkusuz örgütlerin parti adına yaptığı çalışmalar da partinin davranış tarzını göstermesi açısından önemlidir, ancak parti üyelerinin çalışmalarının hedef kitleye ulaşması parti liderleri kadar medyada yer bulamamakta ve kısıtlı bir alanda kalmaktadır. Diğer taraftan parti kurumsal davranışının oluşması sürecine bir bütün olarak yaklaşılması gerekmekte ve tüm üyelerle birlikte yönetimin de aynı davranışı sergilemesi gerekmektedir. Siyasal partilerde başlıca kurumsal davranış kodlarını etik değerler, toplumla ilişkiler, parti üyelerinin davranışları, çevreye duyarlılık, doğru ve zamanında bilgilendirme ve sosyal sorumluluk anlayışı gibi noktalar üzerinden okumak mümkündür. Bu davranış kodları partilerin web siteleri üzerinden incelendiğinde parti ile ilgili birtakım ipuçlarına ulaşılabilmektedir.

Tablo 4. Siyasal Partilerin Web Sitelerinde Kurumsal Davranıșa Illișkin Değerlendirme Ölçeği Formu

\begin{tabular}{|l|l|l|l|l|}
\hline İșaretlemeler: + var,- yok, $x$ yeterli değil & AKP & CHP & HDP & MHP \\
\hline Etik değerler & - & - & - & - \\
\hline Parti üyelerinin davranıșları & + & + & + & - \\
\hline Bilgilendirme davranıșı & + & + & + & + \\
\hline Toplumla ilișkiler & + & + & + & - \\
\hline Sosyal sorumluluk & + & + & - & - \\
\hline Çevreye duyarlıı & + & + & + & - \\
\hline
\end{tabular}


Değerlendirme Ölçeği Formu kodlamaları doğrultusunda Adalet ve Kalkınma Partisinin web sayfası incelendiğinde parti davranış kodlarını ilk olarak haberler üzerinden değerlendirmek mümkündür. İncelemenin yapıldığı esnada genel başkan yardımcısının "Hocalı Katliamı"na ilişkin yaptığı açıklama haberi partinin davranışını yansıtan durum olarak nitelendirilebilir. Yine aynı tarihlerde bașbakan ve bakanların Bingöl'de Sevgi Evleri'ni ziyareti haberi de bu bağlamda değerlendirilebilir. Öte yandan partinin yaptığı ve yapmak istediği çalışmalarla ilgili bilgilerde de parti davranışını görmek mümkündür. $\mathrm{Bu}$ bağlamda ana sayfada partinin icraatları olarak verilen bölümde çevreye ilişkin bakış açısı ortaya konulmakta, sağlıklı ve temiz çevreye dikkat çekilirken hedeflerle ilgili bölümde orman ve yeşillik alan sayısının iki katına çıkarılacağı vurgulanmaktadır. Aynı bölümde sosyal hizmet ve rehabilitasyon merkezlerinin kurulacağı belirtilen başlık altında hedefe ilişkin bilgi verilmektedir. Parti ana sayfasında "Yaşlılar Koordinasyon Merkezi" ve "Engelli Koordinasyon Merkezi" linkleri altında bu yönde birimlerin oluşturulduğu ve çalışmalar yapıldığı vurgulanmaktadır. Ayrıca parti adına 3 Aralık 2015'te Dünya Engelliler Günü mesajı yayınlanarak parti davranışının ortaya konulduğu düşünülmektedir.

AKP üyelerinin yaptığı çalışmalar ve katıldıkları etkinliklerin aynı gün içinde web sayfasında kamuya aktarılmasının da zamanında bilgilendirme davranışına örnek olduğu düşünülmektedir. Bir diğer örnek olarak da parti genel başkanının eski başbakanlardan Necmettin Erbakan'ın vefatının beşinci yılında anma toplantısına katılması verilebilir. Aynı şekilde parti genel başkanının Filistinli bir kızın direnişine oy vermesi ile aynı sayfada haber olarak yer alan Elazığ Kadın Kollarının ildeki okulları ziyareti partinin davranış kodlarını yansıtmaktadır. Buna karşılık kurumsal davranış kapsamında değerlendirilen etik değerlerle ilgili herhangi bir bilgiye yer verilmediği görülmektedir.

CHP web sitesi ana sayfasında yer alan genel başkanın "Hocalı Katliamı"na ilişkin mesaj ve Hasan Ali Yücel'in ölümünün 55. yıldönümünde Twitter'dan yaptığı paylaşım kurumsal davranış temsili olarak görülebilir. Aynı sayfada yer alan Kırklareli Kadın Kollarının "Bir İnsan Isınırsa Bir Şehir Isınır" kampanyası ile Ankara Yenimahalle Belediyesinin temizlik filosuna takviye yapıldığı haberi fotoğrafı olarak verilmektedir. Diğer bir haberde de genel başkanın terör saldırısında yaralanan TSK personelini ziyareti sunulmaktadır. Öte yandan CHP'nin etkinliklerini web sitesinde zamanında bilgi akışıyla sunduğu görülmektedir. Genel olarak bakıldığında CHP web sitesinde kurumsal davranış kodlarını yayınlanan haber içeriklerinde görmek mümkündür. Ancak etik değerlere ilişkin parti web sitesinde herhangi bir değerlendirme veya içerik yer almamaktadır.

HDP web sayfasında parti programında "ekoloji ve yaşam mücadelesi" adıyla bir başlık açılarak partinin çevreye duyarlılığı ve enerji politikalarına ilişkin bakışı vurgulanmaktadır. Programda ayrıca partinin farklı kültür ve düşünce gruplarına da eşit uzaklıkta olduğu mesajı verilmektedir. Ana sayfanın ilk haberinde "Halklara özgürlük, dillere eşitlik" başı̆ğıyla yayınlanan 21 Şubat Dünya Anadili günü kutlaması haberinde anadilde eğitim hakkının savunularak Kürt halkının kendi anadillerinde eğitim yapabilmesi anlayışının ifade edilmesi parti davranışının ortaya konulduğunu göstermektedir. Aynı sayfanın diğer bir haberi "17 YıI Sonra 15 Şubat" şeklinde verilerek Abdullah Öcalan'ın yakalandığı tarihe dikkat çekilmektedir. Haberin devamında Abdullah Öcalan'ın "eşit halkların barış içinde yaşamasının önündeki engellerin 
kaldırılması için çabaladığı” belirtilerek HDP'nin yönetim bazında kurumsal davranışı ortaya konulmaktadır. Sayfada yer alan diğer bir haberde ise "Çamur Medyasının Çabaları Beyhude" başlığıyla iktidar-medya bağlantısına dikkat çekilmekte ve konuyla ilgili sert ifadelerle bilgilendirme yapılmaktadır. HDP'de sosyal sorumluluk ve etik değerlere ilişkin kurumsal davranış kodlarına rastlanmamıştır.

İncelenen diğer parti olan MHP'nin web sitesinde kurumsal davranışın kodlarını ortaya koyacak herhangi bir haber veya materyalin yer almadığı görülmektedir. Bununla birlikte sayfanın alt kısmında yer alan "Engelli Koordinasyon ve İletişim Merkezi" linkine girildikten sonra alt sayfalarda engellilerle ilgili verilen soru önergeleri sunulmakta, engellilerle ilgili yapılan ziyaret ve toplantı haberleri alt bölümlerde verilmekte, bu şekilde partinin duruşu sergilenmektedir. Parti web sayfasında toplumla ilişkiler, parti üyelerinin davranışları, etik değerler, çevre duyarlıığı ve sosyal sorumluluk gibi kurumsal davranışı yansıtan etkinliklere rastlanmamıştır.

\section{Sonuc}

En genel hatlarıyla kurumların ne olduğu, ne olmak istediği ve ne yaptığını ortaya koyan unsurlar kurumsal kimliği oluşturmaktadır. Bu kapsamda, çalışmanın sorunu olan siyasal partilerde kurumsal kimlik uygulamalarının web sitelerine nasıl yansıdığı TBMM'de grubu bulunan dört siyasal parti üzerinden analiz edilmiştir. Kurumsal kimliğin temel unsurları olarak kurumsal tasarım, kurumsal kültür, kurumsal iletişim ve kurumsal davranış kodları temel alanı oluşturmuş, bu bağlamda siyasal partilerin kurumsal kimliğinin web sitelerine nasıl yansıtıldığı ortaya konulmuştur. Bir hafta süresince izlenen söz konusu partilerin web sitelerinde kurumsal kimliği yansıtma süreçleri üzerine şu değerlendirmeler yapılabilir:

Kurumsal tasarım açısından bakıldığında siyasal partilerin web sitelerinin genel olarak renk, tasarım, haber ve görsellerin konumlandırılması, hareketlilik gibi noktalarda büyük oranda parti kurumsal özelliklerini yansıttığı görülmektedir. Logoya uygun renk ve yazı karakterleri sayfa düzenine yansıtılmıştır. Ancak AKP ve CHP'de video ve görsel kullanımın zengin olmasına karşın HDP ve MHP'de sayfanın daha durağan olduğu bulgusuna ulaşılmıştır. Özellikle MHP'de lider dışında neredeyse hiçbir yöneticinin görseline yer verilmemiştir. Bu nedenlerle sayfa ziyaretçilerinin sitede uzun süre kalmayabilecekleri sonucuna varılabilir.

Siyasal partilerde kurumsal kültürün yansıtılmasında hedef, vizyon, misyon, parti programları, partinin tarihi, kurucu genel başkanlar, seçim beyannameleri ve semboller ön planda tutulmaktadır. Bu bağlamda CHP ve MHP'nin kurucu genel başkanlar ve tarihe yönelik bilgiler verdikleri görülürken diğer partilerde bu yönde bulguya rastlanmamıştır. Ayrıca belirtilen özelliklerin çeşitli elektronik yayınlarla desteklendiği görülmektedir. Seçim dönemi olmamasına karşın seçim bildirgelerinin daha önceki seçimler de dahil olmak üzere ana sayfalarda özellikle verildiği bulgusuna ulaşıımıştır. Parti programları ve seçim bildirgelerinin birlikte web sayfalarında kullanılmasının partilerin bu çalışmalarda kendilerini en iyi ifade etme biçimi olarak görmesinden kaynaklı olduğunu söylemek mümkündür. Buna karşılık kurumsal normlar, inançlar, semboller ve ritüeller gibi birçok kurumsal kültür unsurunun web sayfalarında gerektiğince yer almadığı gözlenmiştir. 
Analizde ayrıca partilerin kurumsal tasarımdan sonra en çok kurumsal iletişime önem verdikleri görülmektedir. Nitekim tüm partiler genel kitleye yönelik haberler dışında sosyal medya ağlarına ilişkin linkleri ya ana sayfada vermekte ya da twitter ve youtube gibi uygulamaları doğrudan ana sayfa üzerinde gerçekleştirdikleri paylaşımlarla sunmaktadırlar. AKP; AKIM, çağrı merkezi gibi uygulamalarla genel hedef kitleye ulașma çabası verirken iç hedef kitle için AKBiS ve e-posta sistemini kullanmaktadır. CHP bir yandan haber sayfaları ve genel kitleye açık mesaj alanı oluştururken, chp. net uygulamasıyla iç hedef kitleye ulaşmakta hatta bu sistem üzerinden üyelerinden geribildirim almayı amaçlamaktadır. Çağrı merkezi uygulaması MHP'de de yer almakta, ancak HDP'de bulunmamaktadır. Ayrıca MHP'de örgüte yönelik genelgeler de iletişim kanalı olarak kullanılmaktadır. Genel olarak bakıldığında partilerin bu araçlar üzerinden hedef kitleyle iletişim kurmak için farklı yollar kullandıkları görülmektedir.

Kurumsal kimliğin son unsuru olarak kurumsal davranışlar açısından partilere bakıldığında bu yönde yeterli çalışmanın yapılmadığı bulgulanmıştır. AKP ve CHP'nin kurumsal davranış tarzlarını çevreye duyarlılık, parti üyelerinin çeşitli sosyal etkinliklere katılması ve bilgilendirmenin zamanında yapılması olarak görmek mümkündür. Buna karşılık HDP'nin kurumsal davranış tarzını ifade eden ipuçlarının özellikle parti programında vurgulandığı, ayrıca ana sayfada kullanılan haberlerde davranıș tarzına ilişkin diğer üç partiden farklı bir dille sembolize edilen bir yaklaşımın sergilendiği bulgulanmıştır. MHP'nin kurumsal davranış tarzını engellilerle ilgili kurulan merkez ve özellikle parti programı üzerinden verdiği sonucuna ulaşılmıştır. Diğer yandan incelenen konunun siyasal partiler olması ve partilerin de lider temsilleri üzerinden görünürlük kazandığı dikkate alındığında Türkiye'deki siyasal partilerin kurumsal davranışlarının özellikle kişiler üzerinde yoğunlaşmasının anlamsız olmadığı düşünülmektedir.

Sonuç olarak kurumsal kimliğin siyasal partilerin web sitelerine yansıması bağlamında yapılan analizde partilerin öncelikle kurumsal tasarıma daha sonra kurumsal iletişime önem verdikleri, kurumsal kültürü daha düşük düzeyde web sayfalarında yansıtabildikleri, kurumsal davranışı ise en düşük düzeyde sergiledikleri görülmektedir. Buradan hareketler siyasal partilerin de diğer kurumlar gibi halkla iç içe olması ve kendini doğru ifade edebilmesi için web sitelerinde kurumsal kimlik uygulamalarına yönelik çalışmalarını gözden geçirmesi ve yeniden ele almasının uygun olacağı düşünülmektedir. Bu bağlamda kurumsal kimlik unsurlarının partiler düzeyinde yeterli seviyeye getirilebilmesi için çalışmaların yapılması ve bu sürecin kurumsal web sitelerine yansıtılması ile ancak hedef kitleye kendilerini daha iyi ifade edebilecekleri söylenebilir. Öte yandan bu çalışmanın geniş bir alanı kapsayan kurumsal kimliğin siyasal partilerin web sitelerinde yansıtılmasıyla ilgili bir giriș niteliğinde olduğu varsayılarak ileride her bir unsurla ilgili yapılacak ayrıntılı çalışmaların alanı zenginleştireceği düşünülmektedir.

\section{Kaynakça}

Akıncı, Z. Beril (1998). Kurum Kültürü ve Örgütsel İletişim, İstanbul: İletişim Yayınları.

Atak, Metin (2005). "Örgütlerde Resmi Olmayan İletişimin Yeri ve Önemi”, Havacılık ve Uzay Teknolojileri Dergisi, Cilt:2, Sayı:2: 59-67.

Bakan, İsmail, Büyükbeşe, Tuba ve Bedestenci, H. Çetin (2004). Örgüt Sırlarının Çözümünde Örgüt Kültürü Teorik ve Ampirik Yaklaşım. Bursa: Aktüel Yayınları.

Bat, Mikail (2014). "Benzer ve Farklı Yönleriyle Kurumsal İmaj ve Halkla İlişkiler”, Halkla İlişkiler 
Ne Değildir? Ayşen Temel Eğinli (der.) içinde. İstanbul: Say Yayınları: 373-400.

Budak, Gönül ve Budak, Gülay (2014). İmaj Mühendisliği Vizyonundan Halkla Illişkiler, Ankara: Nobel Yayınları.

Dinçer, Ömer (1998). Stratejik Yönetim ve İşletme Politikası.İstanbul: Beta Yayınları.

Doğan, Binali (2012). Örgüt Kültürü. İstanbul: Beta Yayınları.

Erkmen, Turhan (2010). İşletmelerin Başarısındaki En Temel Paradigma Örgüt Kültürü. İstanbul: Beta Yayınları.

Fidan, Mehmet ve Gülsünler, M. Evrim (2003). "Kurum Kimliğinde Kriz Yönetiminin Yeri ve Önemi”. Selçuk Üniversitesi Sosyal Bilimler Enstitüsü Dergisi. Sayı:10: 465-474.

Güçlü, Nezahat (2003). "Örgüt Kültürü”. Kırgızistan Manas Üniversitesi Sosyal Bilimler Dergisi. Sayı:6: 147-159.

Hofstede, Geert (1994). Cultures and Organizations:

InterculturalCooperationanditsImportanceforSurvival, Software of the Mind.London: Harper Collins Business.

Jefkins, Frank (1995). "Kurum Kimliği”. Aydemir Okay (çev.). Marmara Iletişim Dergisi. Sayı: 9: 33-40.

Karcıoğlu, Fatih, Timuroğlu, Kürşat ve Çınar, Orhan (2009). "Örgütsel İletişim ve İş Tatmini İlişkisi - Bir Uygulama. Yönetim Dergisi. Yıl:20, Sayı: 63: 59-76.

Lewis, Dianne (1998). "How Useful a Concept is OrganizationelCulture?" .Strategic Change, Vol:7. No:5: 251-260.

Meech, Peter (2002). "Kurumsal Kimlik ve Kurumsal İmaj”. Halkla İlişkilerde Eleştirel Yaklaşımlar. Derya Tellan (çev.) içinde. Ankara: Vadi Yayınları:127-151.

Melewar, TunkuChik (2003). "Kurumsal Kimlik İnşasını Belirleyen Faktörler: Bir Literatür Taraması". Zeliha Hepkon (çev.), İstanbul Ticaret Üniversitesi Dergisi, Yıl:2, Sayı:4: 175.211.

Melewar, TunkuChik, Hussey, GarethandSrivoravilai, Nopporn (2005). "Corporate Visual Identity: The Re-Brandingof FranceTélécom”.JournalofBrand Management Vol: 12. Issue:5: 379-394.

Okay, Ayla (2013). Kurum Kimliği. İstanbul: Derin Yayınları.

Oktay, Mahmut (1996). İletişimciler İçin Davranış Bilimlerine Giriş. İstanbul: Der Yayınları.

Olins, Wally (1989).Corporate Identity: Making Business StrategyVisible Through Design. London: Thamesand Hudson.

Schein, Edgar H. (1997). Organizationel Culture and Leadership, (2.Ed.). San Francisco: Jossey-Bass Publishers.

Sriramesh, Krishnamurthy, Grunig, James E., ve Buffington, Jody (2005). "Kurumsal Kültür ve Halkla Illişkiler”. Halkla İlişkiler ve İletişim Yönetiminde Mükemmellik. James E. Grunig (der.). Elif Özsayar (çev.). içinde. İstanbul: Rota Yayınları.

Tosun, Nurhan Babür (2003). "Kurumsal İletişim Sürecinde Reklamın ve İmaj Yönetiminin Bütünleşik Konumu”. Marmara Üniversitesi IïBF Dergisi. Cilt:WVIII. Sayı:1: . 173-191. 
Tuna, Muharrem ve Tuna, Ayşen Akbaş (2007). Kurumsal Kimlik Yönetimi, Ankara: Detay Yayıncılık.

Uzoğlu, Sevil (2001). "Kurumsal Kimlik, Kurumsal Kültür ve Kurumsal İmaj”. Kurgu Dergisi. Sayı:18: 337-353.

Uzunoğlu, Ebru, Onat, Ferah, Alikılıç, Özlem Aşman ve Çakır, Sinem Yeygel (2009). İnternet Çağında Kurumsal İletişim. İstanbul: Say Yayınları.

Van Riel, Cees B. M. AndBalmer, John M.T. (1997). "Corporate Identity: TheConcept, ItsMeasurementand Management”. EuropeanJournalof Marketing. Vol.31. No.5-6: 340-355.

Van Riel, Cees B.M. (1995). Principles of CorporateCommunication.London: PrenticeHall.

Vural, Z. Beril Akıncı ve Bat, Mikail (2013). Teoriden Pratiğe Kurumsal İletişim. İstanbul: İletişim Yayınları.

http://www.yargitaycb.gov.tr/belgeler/site/documents/SPartiler14032016.pdf(erişim tarihi: 10.04.2016)

http://www.ysk.gov.tr/ysk/content/conn/YSKUCM/path/Contribution\%20Folders/ Secmenlslemleri/Secimler/2015MVES/96-D.pdf(erişim tarihi: 10.04.2016).

www.akparti.org.tr (erişim tarihi: 28.02.2016)

www.chp.org.tr (erişim tarihi: 28.02.2016)

www.hdp.org.tr (erişim tarihi: 28.02.2016

www.mhp.org.tr (erişim tarihi: 28.02.2016) 